\title{
Antioxidant and calcium binding activities of hydrolyzed oat bran proteins and chromatographic fractions
}

\author{
By \\ Morooj Baakdah
}

A thesis submitted to the Faculty of Graduate and Postdoctoral Affairs in partial fulfillment of the requirements for the degree of

Master of Science

In

Chemistry, Food Science and Nutrition

Carleton University

Ottawa, Ontario, Canada

(C) Morooj Baakdah, 2014 


\section{Table of content}

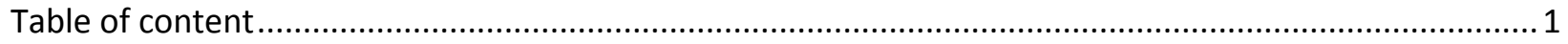

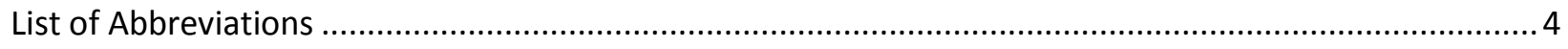

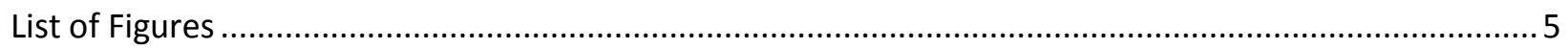

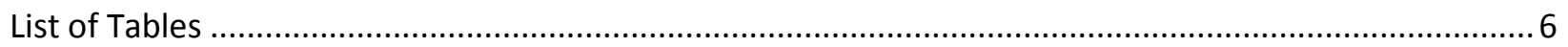

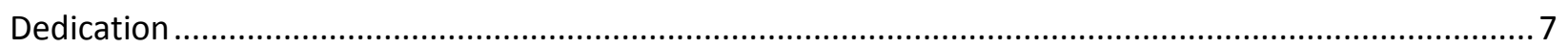

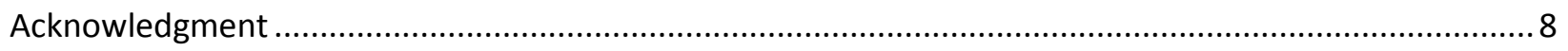

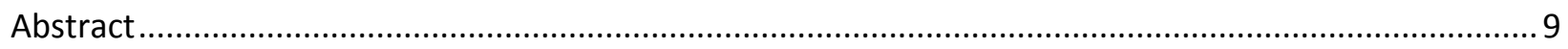

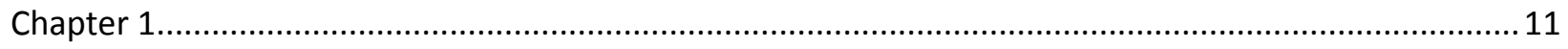

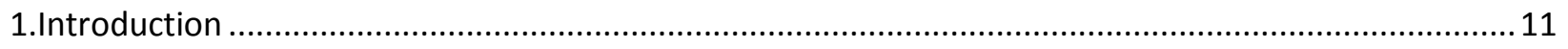

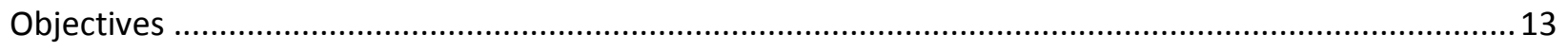

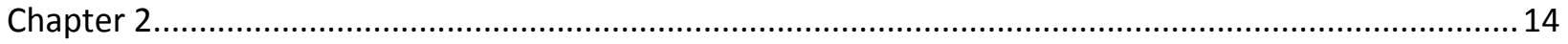

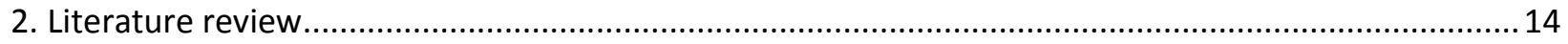

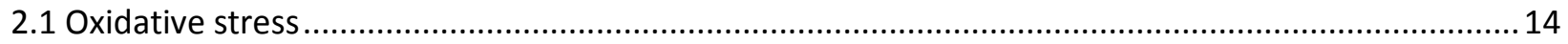

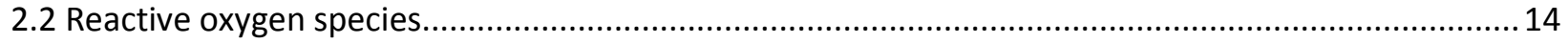

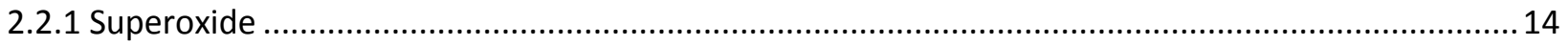

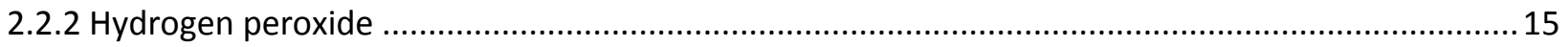

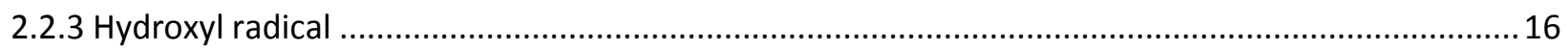

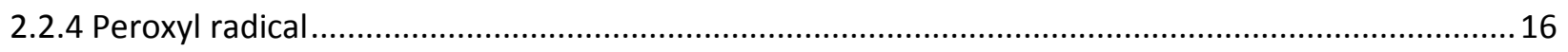

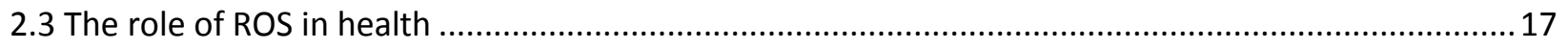

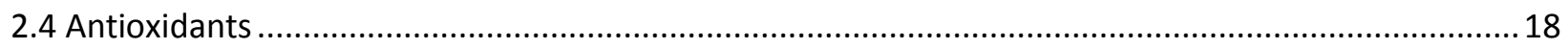

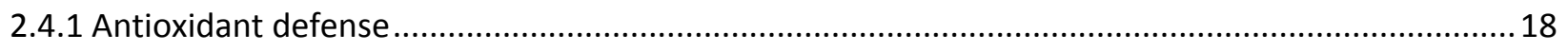

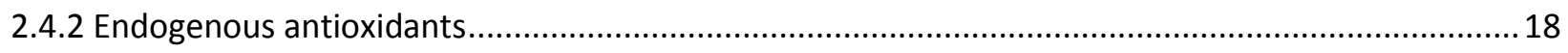

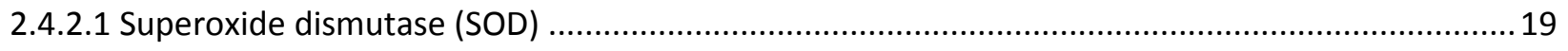

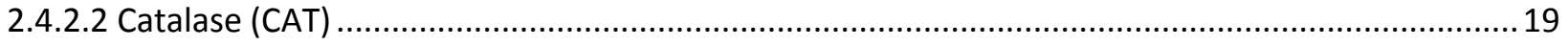




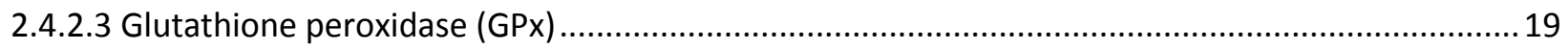

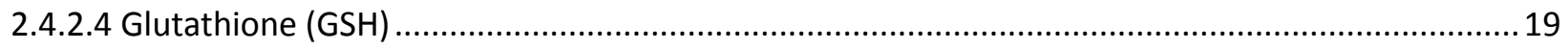

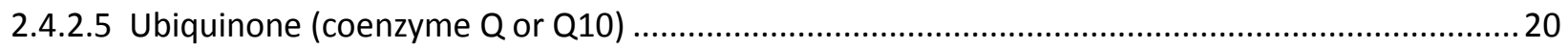

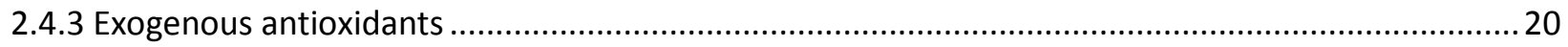

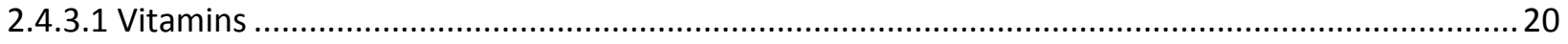

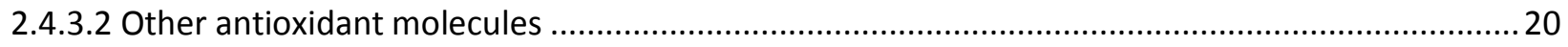

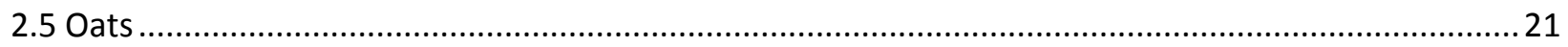

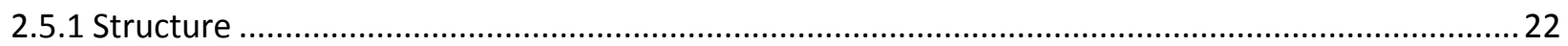

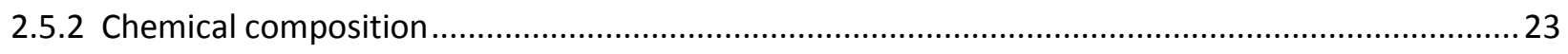

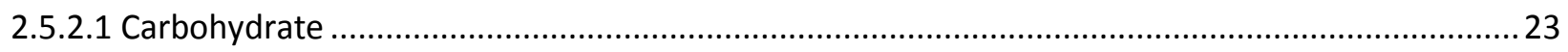

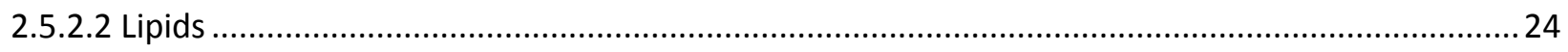

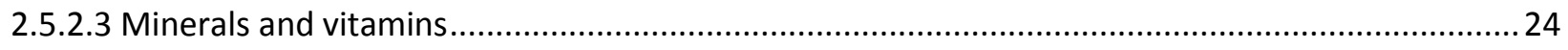

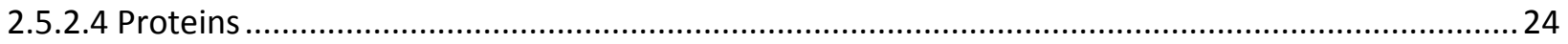

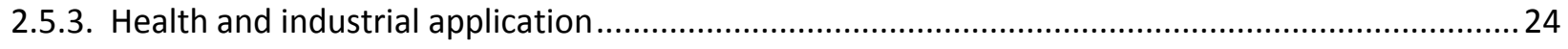

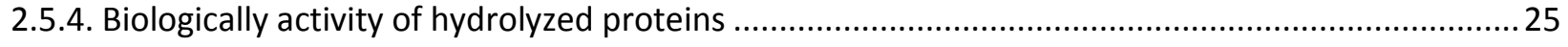

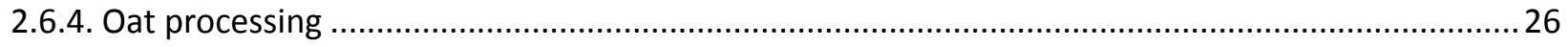

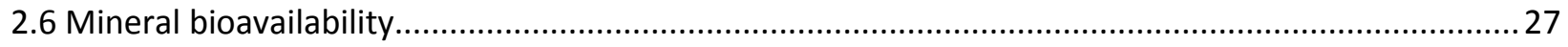

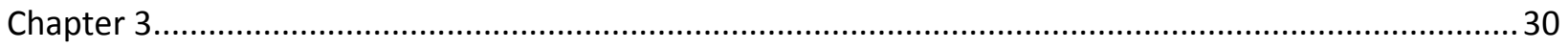

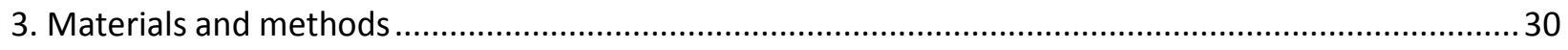

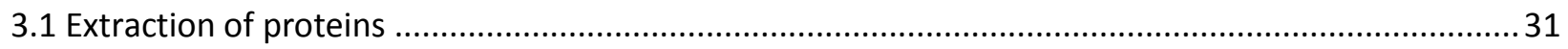

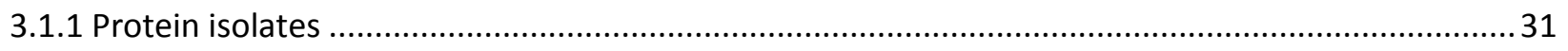

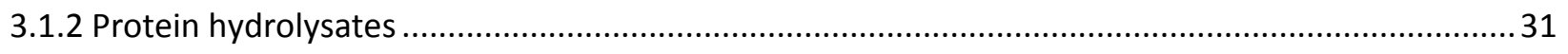

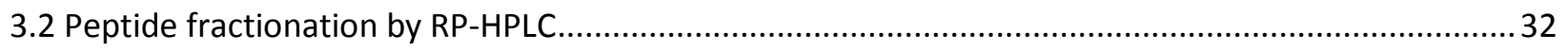

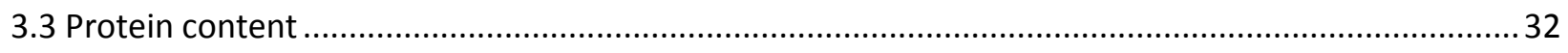

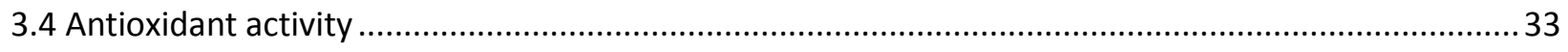


3.4.1 Determination of oxygen radical absorbance capacity (ORAC) ................................................ 33

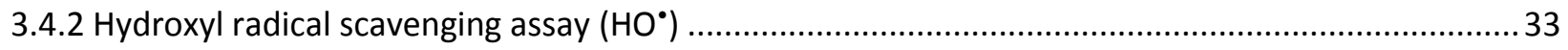

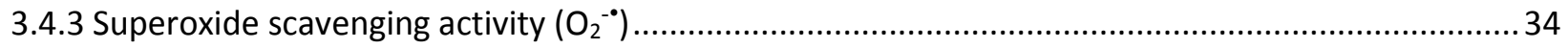

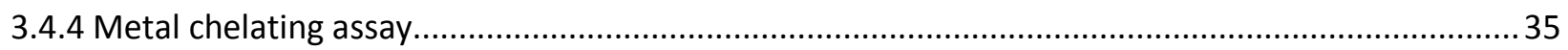

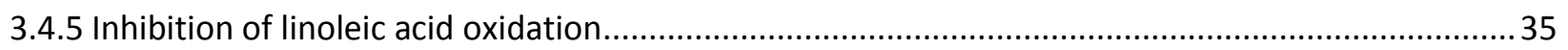

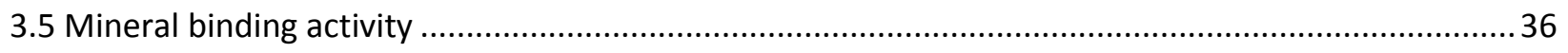

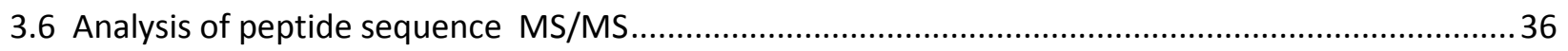

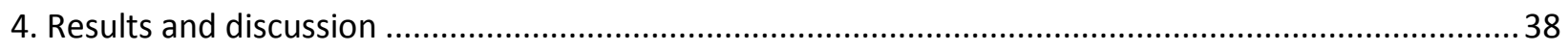

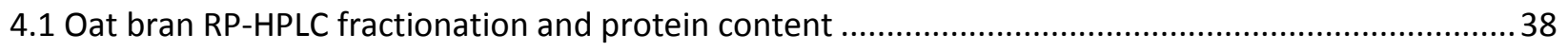

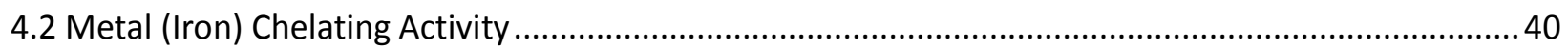

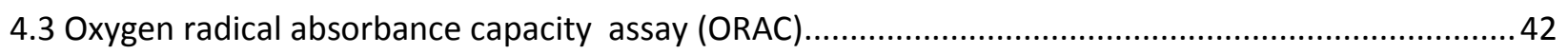

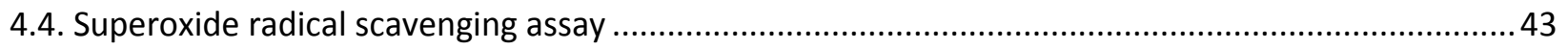

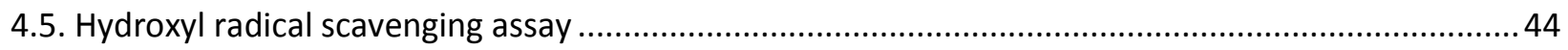

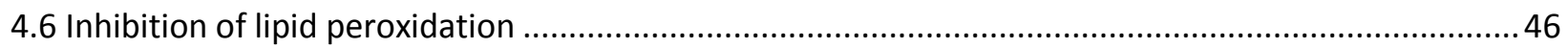

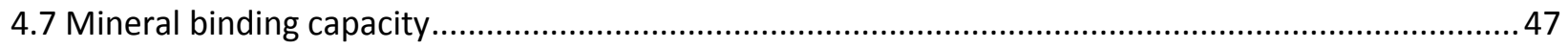

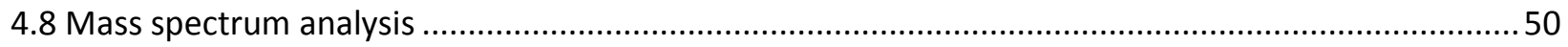

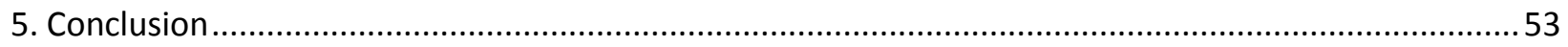

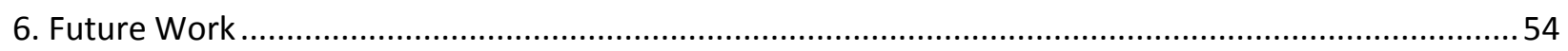

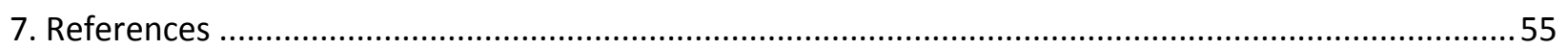




\section{List of Abbreviations}

(OPH)

(ROS)

(RNS)

(LPO)

(LOO*)

(ROOH)

(ROO*)

$\left(\mathrm{L}^{\circ}\right)$

(CAT)

(GPX)

(GSH)

(ORAC)

(RP-HPLC)

(ATP)

(SOD)

(QTOF)

(SD)

$\left(\mathrm{HO}^{\circ}\right)$

$\left({ }^{1} \mathrm{O}_{2}\right)$

(NO*)

$\left(\mathrm{NO}_{2}\right)$

(OONO-)

(MnSOD)

(GSSG)

(K)

(Ca)

(P)

(Mg)

(Zn)

(dd $\mathrm{H}_{2} \mathrm{O}$ )
Oat protein hydrolysate

Reactive oxygen species

Reactive nitrogen species

Lipid peroxidation

Lipid peroxyl radical

Hydroperoxide

Peroxyl radical

Lipid alkyl radical

Catalase

Glutathione peroxidase

Glutathione

Oxygen radical absorbance capacity

Reverse Phase High Performance Liquid Chromatography

Adenosine-5-triphospate

Superoxide dismutase

Quadrupole-time-of-flight

Standard deviation

Hydroxyl radical

Singlet oxygen

Nitric oxide

Nitric dioxide

Peroxynitrite

Manganese superoxide dismutase

Glutathione disulfide

Potassium

Calcium

Phosphate

Magnesium

Zinc

Double distilled water 


\section{List of Figures}

Fig. 1. Oat kernel structure.

Fig. 2. Chromatogram of pooled fractions (1-8) of oat bran protein hydrolysate peptides from RP- HPLC separation

Fig. 3. Metal chelating of oat protein hydrolysate and peptide fractions... 41

Fig.4. Oxygen radical absorbance capacity of oat protein hydrolysate and peptide fractions .43

Fig. 5. Structure of quinone and purpurpogallin .44

Fig. 6. Superoxide scavenging activities of oat protein hydrolysate and peptide fractions .45

Fig.7.Hydroxyl radical absorbance capacity of oat protein hydrolysate and peptide fractions

Fig. 8. Inhibition of linoleic acid oxidation by oat protein hydrolysate and peptide fractions separated by RP-HPLC .49

Fig. 9. In vitro calcium-binding capacity of peptide fractions 5 and 7 . .49

Fig. 10. Total ion count for F5 .50

Fig. 11. MS/MS of Fig. 10 retention time $9-11 \mathrm{~min} .$. 51

Fig. 12. Total ion count for F7 .51

Fig. 13. MS/MS of Fig. 12 retention time $9-13 \mathrm{~min}$ .52 


\section{List of Tables}

Table. 1. Oat protein hydrolysate and peptide fractions protein content ...............................39

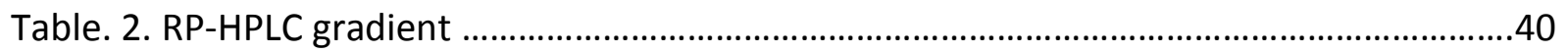




\section{Dedication}

To the people who supported me back home.....

My loving parents and brothers who have been my solid rock and source of motivation. Supporting and encouraging me each step of the way to achieve my dream. 


\section{Acknowledgment}

A thank to God, alhamdullah. A pleasure to thank the many people who were with me throughout this journey.

A great thankyou to King Abdullah foreign scholarship for the support and grant to continue my higher education.

I want to express my gratitude to my supervisor Dr. Apollinaire Tsopmo, for his supervision, great deal of patience, assistance and guidance all the way throughout my research.

A warm thanks goes to all my friends and amazing lab colleagues Rowida, Elizabeth, Sara, Alicia and Natasha for their continuous support and motivating environment to learn and grow.

Finally I owe special thanks to my family, my parents and brothers whose positivity, unconditional support and confidence in me at all times allowed me to persist. 


\section{Abstract}

Recently the interest in peptides from food as bioactive agents has gained attention. Several studies have found that peptides and hydrolyzed proteins possess anti-inflammatory, anti-hypertensive, and antioxidant properties. Oats are a great source of dietary fibers and phenols with demonstrated health benefits. However, proteins or peptides have received little attention. While peptides are inactive in the intact proteins, however once liberated they can possess biological and functional properties. In this research, medium oat bran was pre-treated with viscozyme to degrade carbohydrates and facilitate protein extraction. The isolated proteins were digested with protamex (protease). The oat bran protein hydrolysate produced was separated on reverse phase high performance liquid chromatography into eight fractions (F1-F8) depending on hydrophobicity. The fractions were assayed for their ability to scavenge radicals, chelate metals, inhibit peroxide formation and bind calcium. In the ORAC assay, F7 had the highest $(p<0.05)$ peroxyl radical quenching activity $(844.4 \mathrm{uM} \mathrm{TE} / \mathrm{g})$ compared to OPH and other peptide fractions. An increase of ORAC values from F1 to F7 suggests the possibility of a relationship between the degree of hydrophobicity and the scavenging activity. In the superoxide anion radical assay F3 and F6-F8 had higher activities (45.35-51.2\% inhibition) while in the hydroxyl radical assay, the activity of F4, F7 and F8 were the highest (14-16\% inhibition). Fractionation did not produce a distinct difference in hydroxyl radical scavenging of OPH compared to the peptide fractions. In the metal chelation assay F1 and OPH had the best iron chelating activity $(p<0.05)$ (40.1 and $39.7 \%$ inhibition) in comparison to the RP-HPLC derived peptides (1.22-22.8\%). The chelating activity of F1 is however not due to peptides but probably 
to salts as it contains lower proteins (20\%) compared to other fractions (53-98\%). The calcium binding activity of $\mathrm{OPH}$ and peptides F5 and F7 was weak. Spectrums/MS of +2 and +3 charged peaks in $\mathrm{F} 5$ and $\mathrm{F} 7$ revealed a number of peptides that can be further investigated. 


\section{Chapter 1}

\section{Introduction}

Macromolecules come in four classes, carbohydrates, proteins, lipids and nucleic acids. Recent research has focused on the potential of these macromolecules to provide the human body with biological activity apart from their basic nutritional values. Proteins provide essential functions in the human body. They are built from amino acids, giving each protein its distinctive functional property. Proteins in cells can function as hormones, catalytic enzymes, transport molecules, storage and immunity defense. Protein molecular size is relatively large, which limits their gastrointestinal absorption (Walther, Sieber 2011). During enzymatic hydrolysis short chain amino acids are released from protein intact form. Peptides then released from food products have been shown to possess biological properties such as antioxidant, antiinflammation, immune system modulation, and antimicrobial. In general, peptides are produced through 1) enzymatic digestion, 2) microbial fermentation, and 3) chemical hydrolysis (Korhonen, Pihlanto 2003). For example in south East Asia, fermentation is used as a method for preservation where peptides and other chemicals released by the action of microbial proteases limit food deterioration (Rajapakse et al. 2005). Some of the proteases commonly employed for in vitro digestion of food proteins are alcalase, papin, bromelain, nutrase and protamex (Aristotelis, Anthony \& Anne 2011). Peptides derived from digestion of milk proteins have been extensively studied. There is however a growing interest in investigating peptides from other sources for use in functional foods and nutraceuticals. Data are therefore available 
on peptides with antihypertensive, antioxidant, antihyperlipidemic, antimicrobial and immunomodulatory properties (Korhonen, Pihlanto 2003). Antioxidant activity has been found for some protein hydrolysates and fractions from salmon (Girgih et al. 2013), chickpeas (Chang, Alli 2011) and soybeans (Rho et al. 2007). Grains and cereals are important components of human nutrition as they support around two-thirds of the caloric requirement of the world (Madhujith, Shahidi 2007). In addition to being the primary source of carbohydrates, cereals such as wheat, corn and barley also contain vitamins, trace minerals, dietary fiber and bioactive substances (Foschia et al. 2013). The biological activity of oats has mainly been investigated in relation to its phenolic or fiber content. The main groups of fibers in oats, $\beta$-glucans reduced postprandial glucose concentration in the blood (Wood et al. 1994) and cholesterol level in hypercholesterolemic patients (Braaten et al. 1994). During the extraction of $\beta$-glucans from oats, proteins by-products are rarely used as functional ingredients or sources of bioactive peptides. Many studies have demonstrated the antioxidative properties of cereals by-products such as germ and brans (ex: wheat) (Zhu, Zhou \& Qian 2006). Although, alcalase and trypsin hydrolyzed oat proteins have been found to possess antioxidant properties, the effect of other proteases or chromatography separation has not been investigated. The focus of this thesis is then to find peptide fractions of hydrolyzed oat bran proteins with higher antioxidant properties. In fact, it is well established that oxidative stress is involved in many chronic diseases, and novel radical quenching molecules can be beneficial. Protamex was selected to hydrolyze the proteins because it can overcome the bitterness of protein hydrolysates and therefore can be used in for peptide production in the food industry (Liaset et al. 2002). 


\section{Objectives}

i) Extract proteins from oat brans at optimum $\mathrm{pH}$ and temperature, and in the presence of a cell wall degrading polysaccharide enzyme

ii) Hydrolyze the proteins and fractionate based on the degree of hydrophobicity

iii) Determine antioxidant activities of protein isolates, hydrolyze proteins and purified fractions using various but complementary assays

iv) Determine the calcium binding properties of peptide fractions

v) Determine the sequence of peptides 


\section{Chapter 2}

\section{Literature review}

\subsection{Oxidative stress}

Oxidative stress is defined as an imbalance between the production of oxidants and the ability of antioxidants to eliminate them. Under oxidative stress conditions, constituents of the cell such as proteins, lipids, and DNA are damaged due to excessive production of reactive oxygen species (ROS) and reactive nitrogen species (RNS) (Preiser 2012). Most ROS and RNS have unpaired electrons, making them extremely potent to react with other molecules in order to gain their stability. Non-stabilized ROS and RNS will attack cell membrane and cellular structures, leading to metabolic and structural changes that can be unfavorable to cell survival. ROS are produced in response to inflammatory, aging, radiation and air pollution. Damages caused to different biological molecules such as lipids, proteins and DNA are contributors to the development of various chronic diseases like cardiovascular diseases, cancer, diabetes and Alzheimer (Willcox, Ash \& Catignani 2004).

\subsection{Reactive oxygen species}

The vast majority of oxidants contributing to oxidative stress contain oxygen. A number of them are radicals while others are not.

\subsubsection{Superoxide}

Oxygen $\left(\mathrm{O}_{2}\right)$ is necessary for the survival of all living beings. Oxygen when inhaled goes through the mitochondria of cells where it is metabolized (Cadenas, Sies 1998). In the mitochondria where electron transport chain reactions take place $95-98 \%$ of $\mathrm{O}_{2}$ is used to 
produce adenosine-5-triphospate (ATP) as an energy source. The remaining 2 to $5 \%$ leak out and are converted to radicals instead of water $\left(\mathrm{H}_{2} \mathrm{O}\right)$ (Schneider, Oliveira 2004). Oxygen is incompletely reduced to superoxide radical $\left(\mathrm{O}_{2}^{-\bullet}\right)$, which is further reduced to other reactive oxygen species. Some ROS are radicals such as superoxide anion $\left(\mathrm{O}_{2}^{-\bullet}\right)$, hydroxyl radical $(\mathrm{HO})$, peroxyl radical ( $\left.\mathrm{ROO}^{\circ}\right)$ while others are non-radical derivatives such as hydrogen peroxide $\left(\mathrm{H}_{2} \mathrm{O}_{2}\right)$ and singlet oxygen $\left({ }^{1} \mathrm{O}_{2}\right)$. Another group of reactive species are reactive nitrogen radicals such as nitric oxide (NO), nitric dioxide $\left(\mathrm{NO}_{2}{ }^{\circ}\right)$ and peroxynitrite $\left(\mathrm{OONO}^{-}\right)$(Reuter et al. 2010).

\subsubsection{Hydrogen peroxide}

Hydrogen peroxides are derivatives of $\mathrm{O}_{2}^{-\bullet}$. They do not have unpaired electrons which makes them non radical with a long half-life $(1 \mathrm{~min})$ and fairly low activity compared to $\mathrm{O}_{2}^{-\bullet}$. In response to outside cellular stimuli, $\mathrm{H}_{2} \mathrm{O}_{2}$ is generated by variable cells such as cytokines and hormones. $\mathrm{H}_{2} \mathrm{O}_{2}$ plays a vital role in the synthesis of thyroid hormone, activation of transcription factors and phospholipases activity (Kim et al. 2000). In the presence of mitochondrial manganese superoxide dismutase enzyme (MnSOD), $\mathrm{O}_{2}^{-\bullet}$ is dismutated to $\mathrm{H}_{2} \mathrm{O}_{2}$. In the presence of transition metals like $\mathrm{Fe}^{2+}$ or $\mathrm{Cu}^{2+}$ hydrogen peroxide serves as the main source of $\mathrm{HO}^{\bullet}$ radicals (Stańczyk, Gromadzińska \& Wasowicz 2005). $\mathrm{H}_{2} \mathrm{O}_{2}$ can cause damage to DNA, oxidizing thiol groups in some enzymes leading to their inactivation. In the mitochondria, glutathione peroxidase (GPX) converts $\mathrm{H}_{2} \mathrm{O}_{2}$ into $\mathrm{H}_{2} \mathrm{O}$ and glutathione disulfide (GSSG) in the presence of the cofactor reduced glutathione (GSH) (Schneider, Oliveira 2004). 


\subsubsection{Hydroxyl radical}

Hydroxyl radical is one of the most reactive radicals with a short half-life $\left(10^{-9} \mathrm{sec}\right)$ (Sies, Stahl 1995). This radical can be generated either by the Fenton or the Haber Weiss reactions. The Fenton reaction has two steps, initiated by $\mathrm{O}_{2}^{-\bullet}$ and the presence of metal ions for instance copper or iron. Metal ion ferric $\left(\mathrm{Fe}^{+3}\right)$ is reduced to ferrous $\left(\mathrm{Fe}^{+2}\right)$ and peroxide. In the presence of superoxide dismutase enzymes it catalyzes formation of the non-reactive radical $\mathrm{H}_{2} \mathrm{O}_{2}$. The cleavage of oxygen-oxygen bond in $\mathrm{H}_{2} \mathrm{O}_{2}$ is supported by $\mathrm{Fe}^{+2}$ producing $\mathrm{HO}^{\circ}$. So far there are no known good scavengers of $\mathrm{HO}^{-\bullet}$ in biological systems, however decreasing the presence of transition metals will lead to minimizing of $\mathrm{H}_{2} \mathrm{O}_{2}$ production, to some extent lower its activity (Stańczyk, Gromadzińska \& Wasowicz 2005), (Decker, Van Holde 2011).

Fenton reaction:

$\mathrm{O}_{2}^{-\cdot}+\mathrm{Fe}^{3+} \stackrel{\text { reduced }}{\longrightarrow} \mathrm{O}_{2}+\mathrm{Fe}^{+2}$

$\mathrm{Fe}^{+2}+\mathrm{H}_{2} \mathrm{O}_{2} \longrightarrow \mathrm{Fe}^{3+}+\mathrm{HO}^{\bullet}+\mathrm{HO}^{-}$

Haber Weiss reaction:

$\mathrm{O}_{2}^{-\cdot}+\mathrm{H}_{2} \mathrm{O}_{2} \longrightarrow \mathrm{O}_{2}+\mathrm{HO}^{-}+\mathrm{HO}^{\bullet}$

\subsubsection{Peroxyl radical}

Auto oxidation of lipids takes place in both biological and food systems. Cellular membranes components are targets of oxidation by ROS. The oxidation of unsaturated fatty acids present in cell membranes or foods leads to the formation of high energy lipid peroxyl radical (LOO`). Their generation involves three steps; initiation, progression and termination. 
In the initiation step, free radical $\mathrm{HO}^{\bullet}$ generated from $\mathrm{O}_{2}{ }^{-}$and $\mathrm{H}_{2} \mathrm{O}_{2}$ Fenton reaction removes the hydrogen atom from one carbon of lipid leaving it with an unpaired electron. A $\mathrm{H}_{2} \mathrm{O}$ molecule is liberated. This step involves the presence of metal ions such as Fe. The following step is the propagation; the unpaired carbon reacts with an oxygen atom forming a peroxyl radical. Straightaway, this peroxyl radical reacts with hydrogen. This results in producing hydroperoxide $(\mathrm{ROOH})$ which breaks down to produce lipid alkoxyl, peroxy radical and lipid epoxide. The termination step takes place as free radicals accumulate in cell membrane, therefore triggering chain reactions as free radicals react with each other forming non-radical species. Peroxide molecules will be produced as secondary products, which leads to a reaction with nearby lipids to produce lipid alkyl radical $\left(L^{\circ}\right)$ and restart of the chain reactions (Gill, Tuteja 2010).

\subsection{The role of ROS in health}

Reactive species are byproducts of normal aerobic metabolic processes. So their production is unavoidable, in fact they are of importance in a number of physiological processes as well as having a role in diseases (Rahman 2007). They play a role in signaling pathways for example in response to growth factor stimulation. They contribute in the regulation of many cellular processes, proliferation, growth, apoptosis, regulation, migration and contraction. Macrophages and neutrophils generate ROS (example: hydrogen peroxide) to eliminate the bacterial or microbial infections via phagocytosis (Briegera et al. 2012) . 


\subsection{Antioxidants}

Antioxidants or reducing molecules are used to quench ROS or RNS then, delay or prevent oxidative stress. The human body has a self-mechanism to control ROS production and maintain the redox balance. Antioxidants counteract the damaging effects of ROS and they can either be endogenous or exogenous (Kumar 2011).

\subsubsection{Antioxidant defense}

All organisms have a defense mechanism. For example, in response to bacterial or viral infection the immune system produces white blood cells to fight the infection partly through its ROS production. The majority of excess ROS produced by the electron transport chain are eliminated by the cellular antioxidant defense mechanism via enzymatic and non-enzymatic reactions. Molecules present in the diets can also improve the defense system; diets consisting of whole grains, vegetables, and fruits have therefore been associated with reducing oxidative stress and related chronic diseases. This is because they are full of phytochemicals, vitamins, minerals, amino acids and peptides that can reduce harmful free radicals (Mandal et al. 2009).

\subsubsection{Endogenous antioxidants}

The endogenous defense system is comprised of enzymes that convert reactive species to less reactive entities or to completely non-reactive molecules. The system also includes molecules that can directly scavenge radical species or chelate free metals that often serve as initiator of free radical damages. The main enzymes and radical scavengers are described in the following sections. 


\subsubsection{Superoxide dismutase (SOD)}

SOD is produced in both prokaryotic and eukaryotic organisms. This enzyme requires metal ions such as iron, manganese, copper and zinc to function. It is the first defense line to dismutate $\mathrm{O}_{2}^{-\bullet}$ radical to $\mathrm{H}_{2} \mathrm{O}_{2}$, since $\mathrm{O}_{2}^{-\bullet}$ is the precursor of other radicals (Nordberg, Arner 2001). The reaction is displayed below:

$$
2 \mathrm{O}_{2}^{-\bullet}+2 \mathrm{H}^{+} \stackrel{\mathrm{SOD}}{\longrightarrow} \mathrm{H}_{2} \mathrm{O}_{2}+\mathrm{O}_{2}
$$

\subsubsection{Catalase (CAT)}

Catalase enzyme protects cell from hydrogen peroxide. It catalyzes the conversion of hydrogen peroxide to water and oxygen molecule (Mate's, Pe'rez-go'mez \& De Castro 1999)

$$
2 \mathrm{H}_{2} \mathrm{O}_{2} \stackrel{\text { CAT }}{\longrightarrow} 2 \mathrm{H}_{2} \mathrm{O}+\mathrm{O}_{2}
$$

\subsubsection{Glutathione peroxidase (GPx)}

GPx is a tetrameric enzyme that reduces $\mathrm{H}_{2} \mathrm{O}_{2}$ and hydroperoxides ( $\left.\mathrm{LOOH}, \mathrm{ROOH}\right)$. It uses selenocysteine found in the active site for its activity. In the process, GSH is converted to glutathione disulfide (GSSG) (Margis et al. 2008).

$$
\mathrm{H}_{2} \mathrm{O}_{2}+2 \mathrm{GSH} \stackrel{G \mathrm{PP}}{\longrightarrow} 2 \mathrm{H}_{2} \mathrm{O}+\mathrm{GSSG}
$$

\subsubsection{Glutathione (GSH)}

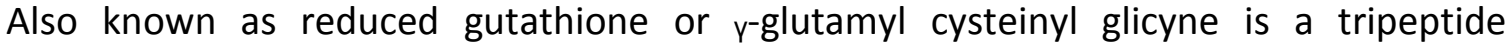
containing sulfhydryl group. It is found in great quantity in all cells. It reduces $\mathrm{H}_{2} \mathrm{O}_{2}$ to $\mathrm{H}_{2} \mathrm{O}$ and $\mathrm{O}_{2}$ by donating electron to hydrogen peroxide. Oxidised glutathione (GSSG) is then reduced to GSH in the presence of NADPH. It protects cell membrane from oxidation by donating proton to lipids (Gill, Tuteja 2010), (Rahman 2007). 


\subsubsection{Ubiquinone (coenzyme $Q$ or Q10)}

This quinone molecule is present in the mitochondria exert as an energy transporter through oxidation reduction reactions. In its reduced form CoQ donates electrons hence its antioxidant function. In cell membranes CoQ protects lipids from oxidant attacks. CoQ can also regenerate oxidised forms of lipid soluble vitamin E and DNA bases (Prakash, Sunitha \& Hans 2010).

\subsubsection{Exogenous antioxidants}

\subsubsection{Vitamins}

A number of micronutrients like vitamins and minerals regulate the redox system. Vitamin $E$ is found in the intercellular membrane, due to its lipid soluble property. The most active form of vitamin $E$ is $\alpha$-tocopherol. It plays a role in inhibiting oxidation of lipid and it is converted in the process to tocopheryl or tocopheroxyl (Hensley et al. 2004), (Pryor 2000). Vitamin C can reduce tocopheroxyl radical thereby regenerating vitamin E (Rahman 2007).

\subsubsection{Other antioxidant molecules}

Food also contains non-nutrients generally referred to phytochemicals and that possess biological functions. Polyphenols are one of the main groups and have shown to have antioxidant properties. They are found in vegetables, fruits, chocolate, and legumes. Polyphenols are secondary metabolites having a defensive role in plants. They generally possess an aromatic ring and one or more hydroxyl groups. Depending on their structures, and the number of rings, polyphenols can be grouped into phenolic acids, flavonoids and lignans. 
As mentioned earlier, their defensive role is in protection of plants from UV rays and pathogen attacks. Moreover, polyphenols give food their distinctive flavor, bitterness, odor and color (Pandey, Rizvi 2009). Oats and other cereals are also good sources of phytochemicals with demonstrated biological activities.

\subsection{Oats}

Oats (Avena sativa L.) rank sixth in the world cereal production statistics after wheat, maize, rice, barley and sorghum (Ahmad et al. 2014). According to archaeologists, oats are crops that were found in the Middle East and particularly in the Mediterranean Sea since 2000 B.C.; other sources indicate that oats originated from Egypt (Surek et al. 1997). Russia is the biggest oat producer. The top exporters are Argentina, Australia, Canada, Finland and Sweden

(Stevens et al. 2004). According to Saskatchewan Ministry of Agriculture (Saskatchewan ministry of agriculture. September 2011) oats were introduced in the mid 1700 as a stable food for new settlers in the western region of Canada. An optimum climate for oats to grow is cool and moist. Livestock feed is the primary use of oats and along with straw, hay, chaff accounted for $74 \%$ of the world's total oat usage in 1995 and 2005, according to the U.S. Department of Agriculture (USDA). Oats are also part of the human diet. They are consumed in the form of oatmeal, flour, bran and oat rolled (mainly in breakfast cereals or added to other food products). Whole grain oats are a good source of fibers, protein, minerals and antioxidants (Strychar 2011). 


\subsubsection{Structure}

Oats kernel is composed of Hull, bran, endosperm and germ. Hull or husk is the external part of grain making up for $30-40 \%$ of total weight. It is inedible made of cellulose. When hull is removed during oat processing we are left with oat groat. The bran which is edible part is loaded with vitamins, minerals, antioxidants, $15-22 \%$ proteins, $8.6 \%$ lipids and $10.4 \% \beta$ glucans. Bran is made of aleurone and subaleurone layer. The endosperm is the dominant starchy part representing $55-70 \%$ of kernel weight. The germ makes up only $3 \%$ of total oat kernel Figure 1. (Arendt, Zannini 2013).

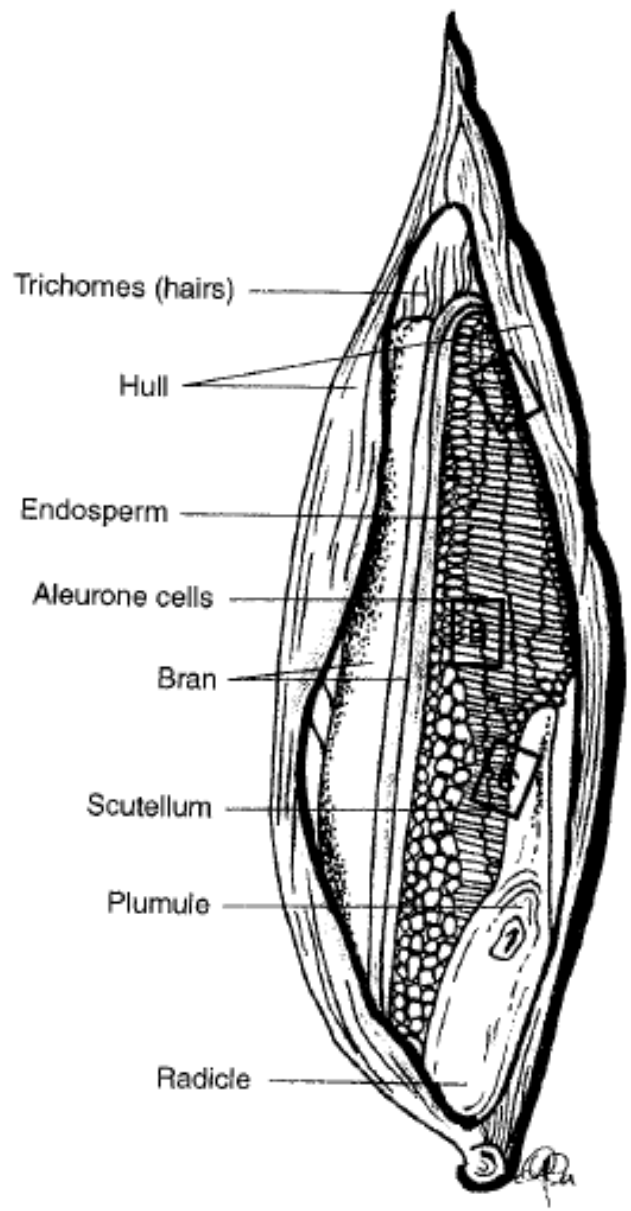

Fig. 1. Oat kernel structure 


\subsubsection{Chemical composition}

Oats are composed of carbohydrates, proteins, fibers along with vitamins and minerals. The quantity of each constituent varies due to genetic and environmental factors (Welch, Hayward \& Jones 1983).

\subsubsection{Carbohydrate}

They make up the majority of oat $90 \%$. Starch represents most of the carbohydrates with minor non-starch polysaccharides for instance $\beta$-glucan and cellulose (Matz 1991).

\subsection{Starch}

Starch is mainly stored in the endosperm 40-50 \% (Sayar, White 2011). Oat starch polysaccharides amylose and amylopectin form 98-99\%. Amylopectin contains linear $\alpha(1 \rightarrow 4)$ bonds then starts to branch every 24-30 glucose unit $\alpha(1 \rightarrow 6)$ linkage. Amylose is a linear polysaccharide made of $\alpha(1 \rightarrow 4)$ bond with few $\alpha(1 \rightarrow 6)$ branch bonds (Tester, Karkalas \& Qi 2004).

\subsection{Fiber}

Oat contains water soluble (4.1 - $4.9 \%)$ and non-soluble fibers (6- $7 \%$ ). Water soluble fibers include pectin, gum and mucilage and $\beta$-glucan. Non soluble fibers composed of lignin and cellulose. Water soluble fibers have viscous property that is beneficial for many health and industrial applications.

$\beta$-glucan is an unbranched polysaccharide containing $(1 \rightarrow 4)$ and $(1 \rightarrow 3)$ glucopyranosyl units. Oats are a rich source of $\beta$-glucan fiber distributed between cell wall of endosperm and bran after barley (Arendt, Zannini 2013). 


\subsubsection{Lipids}

Dietary lipids provide the body with energy and are found in cell membranes. Oats have high lipid content compared to other cereals. Triglyceride is the main lipid in oats with trace amounts of phospholipids and sterols. The unsaturated fatty acids linoleic acid and oleic acid are in oats (Lásztity 1998).

\subsubsection{Minerals and vitamins}

Oats contain minerals $(\mathrm{K}, \mathrm{Ca}, \mathrm{P}$, and $\mathrm{Mg}$ ) and trace minerals $(\mathrm{Fe}, \mathrm{Cu}, \mathrm{Zn}$, and $\mathrm{Mn})$. Oat groats are also a great source of most water-soluble B vitamins (thiamin, riboflavin, niacin, vitamin $\mathrm{B} 6$ and folate) and fat-soluble vitamin $\mathrm{E}$. Vitamin $\mathrm{E}$ is an antioxidant and protects lipids in cells. The presence of vitamin C, B12, A and D in oat is minimal (Welch 2011).

\subsubsection{Proteins}

Proteins in oat range from $15-20 \%$. The majority are stored in the embryo (>30 \%), bran (20\%), endosperm (10\%) and hull (> 2\%). Globulin is the most abundant storage protein. On the other hand, prolamins are the most abundant storage proteins for other cereals wheat (40-50\%), rye (30-50\%) and barley (35-45\%). Prolamin content in oats is lower (10-15\%). Depending on solubility proteins in seeds are divided in to four forms, albumin, prolamin, glutenin and globulin (Arendt, Zannini 2013).

\subsubsection{Health and industrial application}

Health benefits of oats are connected to their fiber content. Non soluble fibers have water retain properties which lead to increased fecal bulk (Butt et al. 2008). $\beta$-glucan have a role in lowering low density lipoprotein (LDL) and hypercholesterolemia (Truswell 2002). It 
forms viscous solution when mixed with water. The increase of viscosity lowers the reabsorption of bile acid therefore; more bile acid is excreted in feces. In addition this increase of bile acid excretion stimulates liver synthesis of bile acids from cholesterol, removing cholesterol from blood stream leading to decreasing cholesterol level (Lia et al. 1997). In 1997 the Food and Drug Administration (FDA) approved a health statement that consumption of soluble fiber from whole oats reduces the risk of coronary heart disease (CHD) (FDA 1997). Incorporation of oats also contributes in lowering the glucose index thus weight loss. Fiber intake decreases the glucose and insulin levels due to delayed reabsorption of glucose in intestine. Moreover, oat fibers have been used in pharmaceutical and cosmetic industry as skin moisturizers, creams and ability to decrease recovery of wounds. The lipid content of oats is higher than other grains. Unsaturated fats linoleic acid and oleic acid are dominant (Lásztity 1998) (Peterson 2004).

\subsubsection{Biologically activity of hydrolyzed proteins}

Peptides and hydrolyzed proteins have been found to possess various activities. Their function is generally affected by the nature of protease used and the sequence of resulting peptides (Sarmadi, Ismail 2010). Although peptides in milk possess good calcium binding properties that can enhance their absorption (Scholz-Ahrens, Schrezenmeir 2000), the search for other calcium binding peptides specifically from plants is of great interest. Plant proteins are cheaper than those from animals and will be preferred by users like vegetarians. Proper calcium absorption is important for bone density and the prevention of rickets and osteoporosis. Food proteins from different sources have been shown to be effective in calcium absorption. Wheat 
germ proteins hydrolyzed with alcalase resulted in peptides with mineral binding capacity in vitro, cell and animal model (Kodama et al. 2004). In animal proteins the presence of phosphate groups is important for binding activity (Meisel 2004) (Jiang, Mine 2001). In addition, it is believed that the presence of charged amino acids (glutamate, arginine, aspartate and glycine) and hydrophobicity are important for the calcium binding of peptides (Liu et al. 2013). Other activities such as antioxidant, anti-hypertensive, anti-inflammation, and anticancer have been reported for cereal peptides. Blood pressure lowering peptides of buckwheat lactic acid fermented were demonstrated in rats (Koyama et al. 2013). Rice endosperm proteins digested with various proteases possessed lipid peroxidation activities (Zhang et al. 2010). In rat models, corn peptides inhibited angiotensin converting enzyme which is involved in blood pressure increase (Huang et al. 2011). The antioxidant activity of some peptides is related to the presence of aromatic amino acids (Beermann et al. 2009). The activity of hydrolyzed proteins can be enhanced by separation based on hydrophobicity, charge, or size. In a previous study, hydrophobic separation (RP-HPLC) of hemp seed proteins digested with pepsin produced fractions with stronger free radical scavenging, lipid peroxidation and metal chelation activities than the non-fractionated samples (Girgih, Udenigwe \& Aluko 2013). There is however no data on the activity of HPLC fractions from digested oats.

\subsubsection{Oat processing}

Like all grains, oats are consumed by both humans and animals. Oats milling process were basic until late nineteen century. In general, there are couple of steps for oat milling and processing: cleaning, hulling, hydrothermal treatment and flaking. Oats have been in human 
food in Europe back in the first century. In England, Scotland and Ireland oats are eaten in porridge, puddings and baking (Arendt, Zannini 2013). Moreover, due to the increased awareness about healthy lifestyle, people are consuming more whole grains in their diet. Oats can be taken in different forms: whole grain the most nutritious form; steel cut oats which are no different than whole oats except they take less time to cook in comparison, and rolled or flaked oats which are heat treated and form the majority of oat products for human use. They are faster to cook and digested. The oats are steamed and rolled, a variety of flaked oats are produced depending on the degree of processing. Rolled regular oats are steamed and rolled. On the other hand, instant rolled as the name implies are cooked even faster. They are steamed and rolled for a longer time giving them a unique texture. Oats can also be added as flour in baking, stews and soups (Whole grains council 2013).

\subsection{Mineral bioavailability}

Trace minerals play a vital role in many biological processes of the body. They are for example essential for optimum growth and development. They also function as catalysts in several enzymes and hormones, and are important for the formation and maintenance of bone structures (Nollet et al. 2007). Calcium is the most abundant, with $99 \%$ stored in bones and teeth and $1 \%$ distributed in cellular fluids (Theobald 2005). It plays a role in the signaling of nerve impulse which then activates muscle fibers and allow them to contract. The process is initiated when calcium ions are passed into muscle cells through specific channels and by binding to receptor proteins. Binding of calcium to troponin protein triggers multi-steps cascades necessary for muscle contraction (Clapham 2007). Calcium also has a role in blood 
coagulation by both intrinsic and extrinsic pathways. After a cut or damage of blood vessel wall; platelets, clotting factors and other cells are activated and move towards site of injury. The release of variable complex factor named thromboplastin (phospholipid and lipoprotein complex) occurs. This complex along with factor VII and calcium ions initiate conversion of inactive $\mathrm{X}$ factor to its active form. Factor $\mathrm{X}$ reacts with phospholipids and factor $\mathrm{V}$ to form prothrombin complex. Prothrombin is converted to activated enzyme thrombin in the presence of calcium ions; it catalyzes the conversion of clotting factor fibrinogen to end blood clotting product fibrin (Joshi \& Mendhurwar 2010). On the structural level, calcium is essential for bone and teeth health along with other minerals such as phosphate and magnesium (Theobald 2005). Because of its importance, it is essential for humans to consume the proper amount of calcium. There are many factors that can influence bioavailability. For example, the absorption of calcium is limited by antagonists in the diet, such as phytates which bind minerals in the body making them insoluble (or non-digestible), and as a result hinder their absorption in the intestinal cells (Nollet et al. 2007). Molecules that can bind minerals and remain digestible in the small intestine can therefore increase their bioavailability. Bovell-Benjamin, Viteri \& Allen 2000, reported that commercially produced ferrous bisglycinate, protected iron from food inhibitors and enhanced iron absorption by four times compared to ferrous sulphate. Histidine and methionine amino acids have been applied to improve zinc bioavailability (Lönnerdal 2000). Hydrolyzed food proteins have been investigated for their ability to bind minerals and potentially improve their bioavailability. In vitro studies have reported mineral binding activities of hydrolyzed proteins from plants such as chickpea (Zhang, Miao \& Jiang 2011), sesame (Wang, Ao 2012), sunflower (Megías et al. 2008); and animals such as anchovy (Wu Zhao \& Zen 
2012) , pollock skin (Guo et al. 2013), and oyster (Chen et al. 2013). In vivo, organic minerals are better absorbed than inorganic ones. Organic molecules including some peptides can protect divalent metals (e.g. calcium) against dietary antagonists, adverse interactions and competition with other minerals in the digestive system making them more bioavailable. Moreover, calcium binding peptides may carry ions across the gastrointestinal tract. Lv et al. 2008 demonstrated that soybean protein hydrolysate (10-30 kDa) chelated calcium ions and improved their bioavailability on intestinal Caco-2 cells. Garcia-Nebot et al. 2013, used Caco-2 intestinal cells to show that casein phosphopeptide (CPP) increased iron and zinc bioavailability. Other cells like human HT-29 cell lines were used to test the role of CPP phosphorylation on calcium uptake and reported that the phosphorylation of acidic motif and the $\mathrm{N}$-terminal side of the peptide were important (Ferraretto et al. 2003). In a rat pup model, CPP enhanced zinc and calcium bioavailability from phytate rich diets (Hansen, Sandstrom \& Lonnerdal 1996). In human fed milk samples, the fact that CPP was found in ileostomy fluid was an indication that CPP survived intestinal passage and might be as functional food ingredient to enhance calcium absorption (Meisel et al. 2003). Although the mineral binding ability of CPP is related to the presence of phosphate group, the binding activity of soybean peptides is more difficult to locate because it is dependent on both sequences and the position of chelating amino acids. It is therefore reasonable to believe peptides from other crops can bind calcium ions and improve their bioavailability. 


\section{Chapter 3}

\section{Materials and methods}

Medium oat bran was kindly supplied by Can-Oat Milling Inc. (Portage La Prairie, MB, Canada), Viscozyme 100 Fungal Beta Glucanase (FBG)/g, sodium carbonate $\mathrm{Na}_{2} \mathrm{CO}_{3}$ sigma ultraminimum $99.0 \%$, sodium hydroxide $\mathrm{NaOH}$ reagent grade $>98 \%$, sodium tartrate dibasic dehydrate, copper (II) sulfate pentahydrate minimum $98 \% \mathrm{CuSO}_{4} .5 \mathrm{H}_{2} \mathrm{O}$, Folin-ciocalteu phenol reagent $2 \mathrm{M}$, L-glutathione reduced (GSH), albumin from bovine serum essentially fatty acid free (BSA), Protease from Bacillus sp. (protamex) minimum activity $1.5 \mathrm{AU}-\mathrm{NH} / \mathrm{g}$ solid, mono- and dibasic potassium phosphates, 6-hydroxy-2,5,7,8-tetramethylchroman-2-carboxylic acid (Trolox), rutin trihydrate, 2, 2'-Azobis(2-methylpropionamidine) dihydrochloride (AAPH), linoleic acid $\geq 99 \%$, calcium chloride $\mathrm{CaCl}_{2}$ and pyrogallol were obtained from Sigma Aldrich (Oakville, ON, Canada). Sodium dodecyl sulfate (SDS) and Tris Base were obtained from Fisher scientific. Ethylene diamine tetra acetic acid (EDTA) was obtained from Bioshop (Burlington, ON, Canada). High-purity water was obtained in the laboratory by an Alpha-Q system (Millipore, Marlborough, MA). Cheesecloth-wipes cotton 46x92cm, Magnetic stirrer plate model corning PC-620D, incubator Thermo scientific MaxQ 4450 and MaxQ 8000, lyophilizer labconco freezone12, E-poche of Biotek, FLx800 of Bioteck (Bio-Tek Instruments, Inc., Winooski, VT), pH meter of fisher science education, centrifuge Thermo scientific Soval legend XTR, centrifuge Thermo electron corporation sorvall legend micro $21 \mathrm{R}$ and reverse phase high performance liquid chromatography HPLC-RP Waters 1525 Binary HPLC Pump equipped with a vacuum membrane degasser, an auto sampler model 2707 with temperature control and a 
2998 photodiode array detector (Waters, Milford, MA), $10 \times 10$ inch magnetic stirrer plate (VWR International, Mont-Royal, Quebec). Microplate fluorescence reader model FLx800 (BioTek Instruments, Inc., Winooski, VT), selective ion electrode calcium of Vernier.

\subsection{Extraction of proteins}

\subsubsection{Protein isolates}

The medium oat bran flour sample $(3 \times 100 \mathrm{~g})$ was defatted by mixing with hexane (1:3 $\mathrm{w} / \mathrm{v}$ ) and stirring for $1 \mathrm{~h}$ at room temperature in a fume hood. Hexane containing the fat was removed by filtration. The defatted bran was left to dry overnight in fume hood, suspended in water 1:10 $(\mathrm{w} / \mathrm{v})$ ratio and mixed to obtain a homogeneous slurry $\mathrm{pH}$ was adjusted to 4.5 using $1 \mathrm{M} \mathrm{HCl}$. Viscozyme, a multienzyme complex that was demonstrated to decrease the viscosity of the slurry and improve protein extraction, was added at a ratio of $3 \mathrm{FBG} / \mathrm{g}$ of defatted bran, followed by incubation at $45^{\circ} \mathrm{C}, 150 \mathrm{rpm}$ for $2 \mathrm{~h}$. At the end of the incubation, the $\mathrm{pH}$ was adjusted to 9.5 with $2 \mathrm{M} \mathrm{NaOH}$ solution and further incubated for $30 \mathrm{~min}$. The alkaline solution was cooled down and centrifuged at $2500 \mathrm{~g}$, for $20 \mathrm{~min}$ and $4^{\circ} \mathrm{C}$. To obtain the protein isolate, the supernatant was collected followed by adjustment to $\mathrm{pH} 4.0$ and centrifugation at $10,000 \mathrm{~g}$ for $40 \mathrm{~min}$ at $4^{\circ} \mathrm{C}$. The obtained protein isolate (precipitate) was washed with water ( $\mathrm{pH} \mathrm{4.0)}$ and centrifuged for $30 \mathrm{~min}$ at $1100 \mathrm{~g}$. Finally, the isolate was dissolved in water, adjusted to $\mathrm{pH}$ 7.0 and freeze dried (Jodayree, Smith \& Tsopmo 2012).

\subsubsection{Protein hydrolysates}

The oat bran protein isolate (19 g) was transferred to beaker suspended in water (209 ml) 1:11 ratio. The $\mathrm{pH}$ was adjusted to 6.5 using $0.1 \mathrm{M} \mathrm{NaOH}$. In 1:20 ratio $0.95 \mathrm{~g}$ Protamex 
enzyme was added. The mixture was incubated at $50^{\circ} \mathrm{C}$ at $130 \mathrm{rpm}$ for $2 \mathrm{~h}$ on shaker incubator.

To deactivate the enzyme the mixture was heated up to $90^{\circ} \mathrm{C}$ for $10 \mathrm{~min}$. It was then cooled down and centrifuged at $5000 \mathrm{rpm}$ for $25 \mathrm{~min}$ at $4^{\circ} \mathrm{C}$ to remove insoluble proteins. Supernatant was collected freeze dried and stored at $-20^{\circ} \mathrm{C}$ until use.

\subsection{Peptide fractionation by RP-HPLC}

Oat bran peptide fractionation was carried out using RP-HPLC. The lyophilized oat bran protein hydrolysates were dissolved in $0.1 \%$ acetic acid at a concentration of $100 \mathrm{mg} / \mathrm{L}$. A volume of $2 \mathrm{~mL}$ pre-filtered through $0.45 \mu \mathrm{m}$ membrane discs, were injected by an auto sampler maintained at $8^{\circ} \mathrm{C}$. Data were collected and processed and analyzed using Waters Empower version 3 software. The analytical column was run onto a column Prep XBridge BEH C18, $130 \AA, 10 \mu \mathrm{m}, 19 \times 150 \mathrm{~mm}$ (Waters). Two different solvents were used to carry out the separation. Solvent A (0.1\% acetic acid in water) and solvent B (methanol 100\% HPLC grade) were pumped through a binary HPLC pump (module 1525). Fractions were eluted from the column at a flow rate of $4 \mathrm{~mL} / \mathrm{min}$ during 54 min using gradients. Detection was carried out by a PDA detector (module 2998) at $280 \mathrm{~nm}$. Fractions were collected using an automated fraction collector (module III) every 2 min over 54 min and pooled into eight fractions according to elution time. Each fraction was concentrated and the solvent evaporated using a BUCHI Rotavapor ${ }^{\oplus} \mathrm{R}-215$ at $45^{\circ} \mathrm{C}$, then freeze-dried at $-50^{\circ} \mathrm{C} 0.05$ mbar and kept at $-20^{\circ} \mathrm{C}$.

\subsection{Protein content}

Protein content of oat bran hydrolysate and fractions were determined using a modified Lowry method (Markwell et al. 1978) three reagents were prepared, reagent A made fresh 2\% 
$\mathrm{Na}_{2} \mathrm{Co}_{3}, 0.4 \% \mathrm{NaOH}, 0.16$ sodium tartarate and 1\% SDS. Reagent B $4 \% \mathrm{Cu}$ SO4 can be stored. Reagent $C$ made fresh mix reagent $A$ and $B$ in 1:7 ratio. In a 1:1 ratio prepare Folin reagent in $\mathrm{ddH}_{2} \mathrm{O}$ also made fresh. Standard solution $100 \mu \mathrm{g} / \mathrm{ml} \mathrm{BSA}$ in $\mathrm{ddH}_{2} \mathrm{O}$ concentrations range 0 - 100 $\mu \mathrm{g} / \mathrm{ml}$. OPH and F1-8 concentration 60 and $80 \mu \mathrm{g} / \mathrm{ml}$ were tested.

\subsection{Antioxidant activity}

\subsubsection{Determination of oxygen radical absorbance capacity (ORAC)}

This assay was performed according to (Huang et al. 2002). A microplate fluorescence reader with fluorescence filters (excitation wavelength 485/20 nm, emission wavelength $528 / 20 \mathrm{~nm}$ ) was used. Potassium phosphate buffer $(75 \mathrm{mM}, \mathrm{pH} 7.4)$ was used to prepare all reagents, standards, samples, and the control. Five concentrations of trolox $6.25,12.5,25,50$ and $100 \mu \mathrm{M}$, were used for standard. Fluorescein dye $(0.082 \mu \mathrm{M})$ and AAPH (153 mM) were both prepared immediately before use. Rutin trihydrate (20 and $10 \mu \mathrm{M})$ was used as control. Fluorescein $(120 \mu \mathrm{L})$ was transferred into the wells followed by addition of $20 \mu \mathrm{L}$ of samples $\left(0.125 \mathrm{mg} / \mathrm{ml}\right.$ ) or blank (buffer). The mixture was incubated for $20 \mathrm{~min}$ at $37^{\circ} \mathrm{C}$ in the built-in incubator and APPH solution $(60 \mu \mathrm{L})$ was added to each well. Data were collected every min for a total of $50 \mathrm{~min}$ and processed. Data were analysed and ran using the Gen5 ${ }^{\mathrm{TM}}$ software. The ORAC values were expressed as Trolox equivalents (TE) using the standard curve.

\subsubsection{Hydroxyl radical scavenging assay $\left(\mathrm{HO}^{\circ}\right)$}

The $\mathrm{HO}^{\bullet}$ scavenging assay was used with some modifications (Li et al. 2008). Oat protein peptide samples and glutathione (positive control) were prepared at a concentration of 2 $\mathrm{mg} / \mathrm{ml}$ in potassium phosphate buffer $(0.75 \mathrm{mM}, \mathrm{pH} 7.4)$ and transferred into a 96-well clear 
microplate $(50 \mu \mathrm{L})$. Buffer was used for blank. The following reagents were then added: 1, 10phenanthroline in buffer $(3 \mathrm{mM}, 50 \mu \mathrm{L}), \mathrm{FeSO}_{4} .7 \mathrm{H}_{2} \mathrm{O}$ in water $(3 \mathrm{mM}, 50 \mu \mathrm{L})$ and $0.03 \%$ aqueous $\mathrm{H}_{2} \mathrm{O}_{2}(50 \mu \mathrm{L})$ in each well, except for the blank (50 $\mu \mathrm{L}$ water). The plate was incubated for $1 \mathrm{~h}$ at $37^{\circ} \mathrm{C}$ with shaking (200 rpm) in a Thermo Scientific MaxQ ${ }^{\mathrm{TM}} 4450$ incubator-shaker. Absorbance was then read at $536 \mathrm{~nm}$ using a Pharmacia Biotech Ultrospec $4000 \mathrm{UV} / \mathrm{vis}$ spectrophotometer run by Gen5 $5^{\mathrm{TM}}$ software. Hydroxyl radical scavenging activity was calculated using the following formula:

$\mathrm{HO}$ • scavenging activity $(\%)=\left[\left(\mathrm{A}_{\text {sample }}-\mathrm{A}_{\text {control }}\right) /\left(\mathrm{A}_{\text {blank }}-\mathrm{A}_{\text {control }}\right)\right] \times 100$

$A$ is the absorbance.

\subsubsection{Superoxide scavenging activity $\left(\mathrm{O}_{2}^{-{ }^{-}}\right)$}

The superoxide scavenging activity was measured according to the method by (Pownall, Udenigwe \& Aluko 2010). Tris-HCl buffer containing 1 mM EDTA (50mM, pH 8.3) was prepared. An aliquot $(80 \mu \mathrm{L})$ of peptide fractions $(1 \mathrm{mg} / \mathrm{mL})$ or glutathione $(1 \mathrm{mg} / \mathrm{mL}$, positive control) were mixed with $80 \mu \mathrm{L}$ of $50 \mathrm{mM}$ Tris-HCl buffer containing $1 \mathrm{mM}$ EDTA (pH 8.3) into a 96-well clear microplate. The assay control contained only Tris- $\mathrm{HCl}$ buffer. Pyrogallol (1.5 mM) was dissolved in $10 \mathrm{mM} \mathrm{HCl}$ and $40 \mu \mathrm{L}$ added to each well. The absorbance was measured at $420 \mathrm{~nm}$ every $20 \mathrm{~s}$ for $4 \mathrm{~min}$ at room temperature using a Biotech Ultrospec $4000 \mathrm{UV} / \mathrm{vis}$ spectrophotometer controlled by $\mathrm{Gen} 5^{\mathrm{TM}}$ software. The reaction rate $\Delta \mathrm{A} / \mathrm{min}$ was calculated and the superoxide radical scavenging activity obtained following the equation: $\mathrm{O}_{2}^{-\bullet}$ scavenging activity $(\%)=[(\Delta \mathrm{A} / \mathrm{min}$ control $-\Delta \mathrm{A} / \mathrm{min}$ sample $) / \Delta \mathrm{A} / \mathrm{min}$ control $] \times 100$ 


\subsubsection{Metal chelating assay}

The metal chelating assay was according to the method of (Zhengjun et al. 2008) with modifications. Oat protein hydrolysate, peptide fractions and GSH (1ml) at a final concentration of $1 \mathrm{mg} / \mathrm{ml}$ was combined with $50 \mu \mathrm{L}$ of $\mathrm{FeCl}_{2}$ solution $(2 \mathrm{mmol} / \mathrm{l})$ and $1.85 \mathrm{ml}$ of $\mathrm{ddH}_{2} \mathrm{O}$. Ferrozine (3-(2-pyridyl)-5, 6-diphenyl-I, 2, 4-triazine-40,400-disulfonic acid sodium salt) (100 $\mu \mathrm{L})$ at final concentration $5 \mathrm{mM}$ was added and vortexed. The mixture was left to incubate at room temperature for $10 \mathrm{~min}$. In a 96 well plate $200 \mu \mathrm{L}$ was pipetted and the absorbance was read at $562 \mathrm{~nm}$ using a Pharmacia Biotech Ultrospec 4000 UV/vis spectrophotometer run by Gen5 ${ }^{\mathrm{TM}}$ software. Chelating effect was calculated using following equation:

Chelating effect $\left.(\%)=\left[\left(\mathrm{A}_{\text {control }}-\mathrm{A}_{\text {sample }}\right) / \mathrm{A}_{\text {control }}\right)\right] \times 100$

\subsubsection{Inhibition of linoleic acid oxidation}

Linoleic acid oxidation was measured according to the method of (Girgih et al. 2013) with some modifications. Oat protein hydrolysates, peptide fractions and GSH $0.5 \mathrm{mg} / \mathrm{ml}$ bran of each sample were dissolved in $50 \mathrm{mM}$ phosphate buffer ( $\mathrm{pH}$ 7.0). In a microcentrifuge vial $0.4 \mathrm{ml}$ of sample was added to $0.4 \mathrm{ml}$ of linoleic acid ( $75 \mathrm{mM}$ in $95 \%$ ethanol) and was left to incubate at $60^{\circ} \mathrm{C}$ for 5 days. The oxidation degree was evaluated every $24 \mathrm{~h}$ by measuring the ferric thiocyanate values. The sample mixture $(50 \mu \mathrm{L})$ incubated with the linoleic acid was mixed with $2.35 \mathrm{ml}$ of $75 \%$ ethanol, $50 \mu \mathrm{L}$ of $30 \%$ ammonium thiocyanate and $50 \mu \mathrm{L}$ of $20 \mathrm{mM}$ ferrous chloride solution in $1 \mathrm{M} \mathrm{HCl}$, the mixture was vortexed. The value was measured by pipetting in a 96 well plate $200 \mu \mathrm{L}$ reading absorbance at $500 \mathrm{~nm}$. The degree of color represents linoleic acid oxidation. 


\subsection{Mineral binding activity}

Calcium - peptide binding capacity was measured according to (Jung et al. 2006) with some modifications. Oat protein hydrolysate and peptide fractions were dissolved in $20 \mathrm{mM}$ sodium phosphate buffer (pH 7.8). In a 1:1 ratio seven different concentrations 200 to 2000 $\mathrm{mg} / \mathrm{L}$ were mixed with $10 \mathrm{mM} \mathrm{CaCl}_{2}\left(\right.$ in $\left.\mathrm{ddH}_{2} \mathrm{O}\right)$. The mixture was incubated at $25^{\circ} \mathrm{C}$ for $30 \mathrm{~min}$ in shaker incubator. Then after the incubation, $\mathrm{pH}$ was adjusted to 7.8 using $\mathrm{NaOH}$ 0.1-0.5 M. In another set of glass tubes, the sample mixture was filtered using $0.45 \mu \mathrm{m}$ membrane disc to remove non-soluble phosphate-calcium complexes. Calcium binding capacity was measured by the calcium selective ion meter.

\subsection{Analysis of peptide sequence MS/MS}

RP-HPLC peptide fractions 5 and 7 were analyzed for their sequence. Protein hydrolysates at $1 \mathrm{mg} / \mathrm{mL}$ in $2 \%$ acetic acid were injected onto a $7 \mathrm{~cm} \times 200 \mathrm{~mm}$ inner diameter trap column, fritted, and packed in-house with $5 \mathrm{~cm}$ of $3 \mu \mathrm{m}$ Magic C18AQ reversed phase packing material (Michrom Bioresources, Auburn, CA) using a pressure vessel constructed inhouse. The trap column was connected in series to a $6 \mathrm{~cm} \times 75 \mathrm{~mm}$ Picofrit analytical column with a tip opening of $15 \mu \mathrm{m}$ (New Objective, Woburn, MA), packed with $5 \mathrm{~cm}$ of Magic C18AQ reversed phase packing material. Peptides were separated using a gradient of $2 \% \mathrm{~B}$ at 0 min, $5 \% \mathrm{~B}$ at $3 \mathrm{~min}, 10 \% \mathrm{~B}$ at $8 \mathrm{~min}, 29 \% \mathrm{~B}$ at $70 \mathrm{~min}, 80 \% \mathrm{~B}$ at $75 \mathrm{~min}$ followed by $10 \mathrm{~min}$ of wash at $100 \% \mathrm{~B}$ and 5 min of re-equilibration at $2 \% \mathrm{~B}, \mathrm{~A}$ and $\mathrm{B}$ are $0.1 \%$ formic acid/water and $0.1 \%$ formic acid/acetonitrile, respectively. Peptides were eluted from the trap and analytical columns at a flow rate of $250 \mathrm{~nL} / \mathrm{min}$, ionized by nanoelectrospray ionization (ESI) and analyzed using a QSTAR XL QqTOF mass spectrometer (AB Sciex, Concord, ON) operating in information- 
dependent acquisition mode over a mass range of 400 to $1500 \mathrm{~m} / \mathrm{z}$. Only ions with charge state $2^{+}$and $3^{+}$were chosen for fragmentation. Mass analysis included a 1-s survey scan followed by two 2-s tandem mass spectrometric scans then two 3-s tandem mass spectrometric scans on the most intense peaks in the spectrum; masses could be sequenced twice before being added to an exclusion list for $90 \mathrm{~s}$. MS/MS data were determined using Mascot (Matrixscience Ltd, Boston, MA). Mass tolerances were set to $\pm 100 \mathrm{ppm}$ and $\pm 0.2 \mathrm{Da}$ for the peptide and fragment ion spectra, respectively; one missed cleavage was considered; no modification was selected; enzyme was to none. Peptides identified by Mascot were manually examined and verified for accuracy. Peptide sequences were matched to the published sequences of all proteins from the National Center for Biotechnology Information non-redundant database (NCBInr).

\section{Statistical analysis}

All data were expressed as mean of standard deviation from replicates. One way ANOVA was used, differences between means were calculated using LSD test. All statistics were analysed with SPSS (IBM SPSS Statistics 21). 


\section{Results and discussion}

\subsection{Oat bran RP-HPLC fractionation and protein content}

Reverse-phase high performance liquid chromatography (RP-HPLC) was used to separate oat protein hydrolysates into different fractions based on the degree of hydrophobicity. The C18 column was the stationary phase, while the mobile phase was a gradient of water and methanol. The separation depends on hydrophobic interactions. Therefore, less hydrophobic molecules (e.g. peptides) have little interaction with the stationary phase, resulting in their rapid elution with high water percentage solvent mixtures. On the other hand, more hydrophobic samples stick longer on the stationary phase and will be eluted later using an increasing content of methanol and decreasing content of water. The gradient used for separation is shown in Table 2. Eight peptide fractions were collected as indicated in Figure 2. Protein contents of the $\mathrm{OPH}$ and peptide fractions measured by the modified Lowry method are presented in Table 1. Protein contents of fractions F3 to F8 ranged from 70.0 to $104.31 \%$. Oat protein hydrolysate contained $68.04 \%$ protein which was lower compared to the fractions (i.e. F3-F8). These findings show that fractionation of oat protein hydrolysate increased the protein content of many fractions. Fractions 1 and 2 had the least protein content ( 25.88 and $14.12 \%$ ) which may be due to presence of salts and sugars that have little binding to the C18 column. Similar finding have been reported for fractions obtained after separation of other hydrolyzed food proteins (Girgih et al. 2013). 


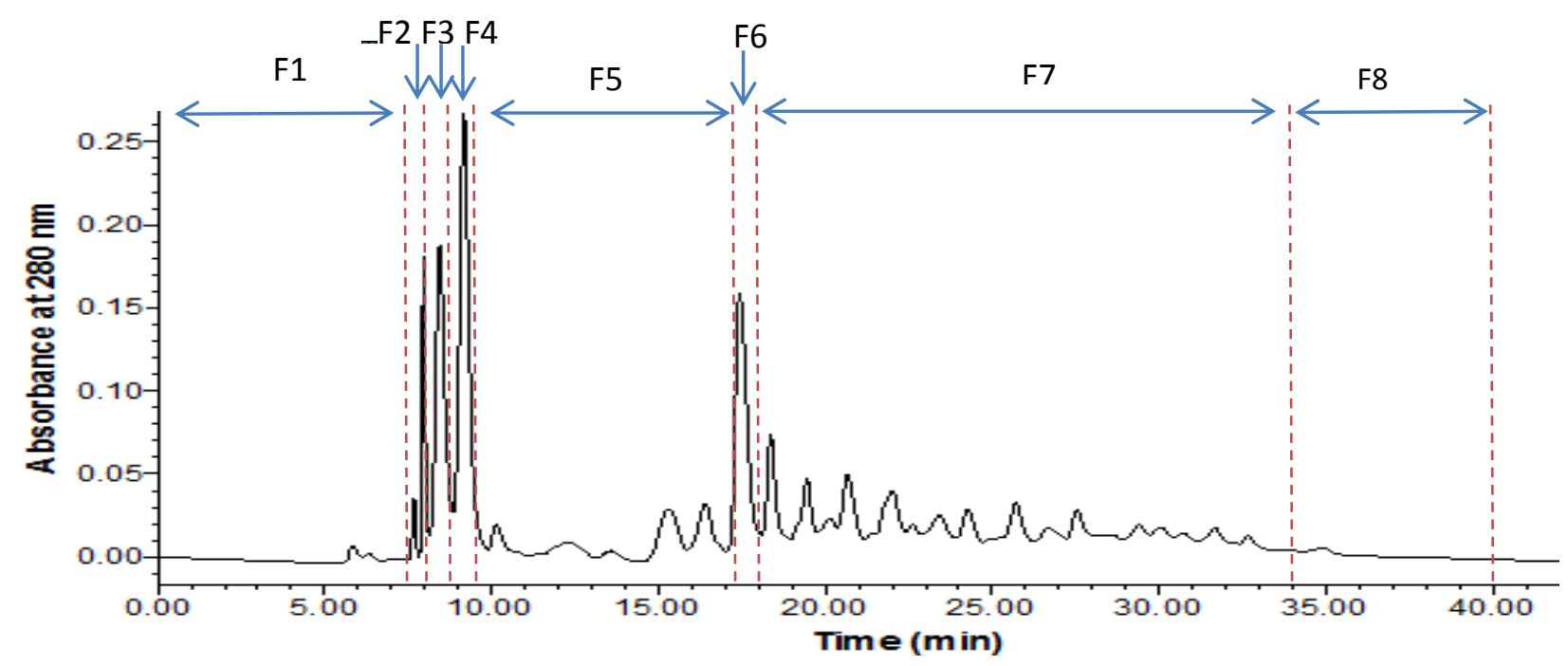

Fig. 2. Chromatogram of pooled fractions (1-8) of oat bran protein hydrolysate peptides from RP- HPLC separation

Table. 1. Oat protein hydrolysate and peptide fractions protein content

\begin{tabular}{|c|c|}
\hline Sample & Protein content (\%) \\
\hline F1 & $25.88 \pm 0.005$ \\
\hline F2 & $14.12 \pm 0.003$ \\
\hline F3 & $77.84 \pm 0.003$ \\
\hline F4 & $84.71 \pm 0.002$ \\
\hline F5 & $81.76 \pm 0.001$ \\
\hline F7 & $104.31 \pm 0.001$ \\
\hline F8 & $70 \pm 0.002$ \\
\hline OPH & $68.04 \pm 0.001$ \\
\hline
\end{tabular}


Table 2. RP-HPLC gradient

\begin{tabular}{|c|c|c|}
\hline Time (min) & $\begin{array}{c}\text { Solvent A } \\
\text { 0.1 \% Acetic acid (\%) }\end{array}$ & Methanol (\%) \\
\hline 0 & 95 & 5 \\
\hline 5 & 95 & 90 \\
\hline 35 & 10 & 90 \\
\hline 40 & 10 & 5 \\
\hline 45 & 95 & 5 \\
\hline 55 & 95 & 0 \\
\hline 57 & 100 & \\
\hline
\end{tabular}

\subsection{Metal (Iron) chelating activity}

As shown in Figure $3, \mathrm{OPH}$ had the strongest $(\mathrm{p}<0.05)$ ferrous iron chelating ability (39.7\%) in comparison to activities of peptide fractions F2 to F8 (1.22-22.8 \%) and control GSH (5.78\%). The activity of OPH is similar to the reported chelating value for walnut protein hydrolysate (40\%) (Ning et al. 2012). Cysteine has been suggested to play a role in the chelating activity of peptides. However, its unique role may be limited, as GSH a cysteinecontaining peptide used as control only had $5.8 \%$ ferrous ionchelating activity. Other studies have also reported a low ferrous ion chelating property for GSH (Zhengjun et al. 2008). Among fractionated peptides, fraction 1 exhibited the highest chelating activity. As discussed in section 4.1, the fraction contains salts and negative charged ions like chlorine carboxylate on 
sugars probably contributed to its activity. Amongst the other fractions F7 better chelated ferrous ions with chelating activity (22.8\%), almost half the activity of OPH $39 \%$ and F1 $40.2 \%$. Carboxylic groups in amino acids like glutamate and aspartate have excess electrons that enhance electrostatic and ionic interactions with iron thereby increasing chelating activity of peptides that contain them (Lijuan et al. 2008). According to Girgih et al. 2013, Prior, Wu \& Schaich 2005 , histidine at the N-terminal of peptides can be effective in metal ion chelation. This proprety is related to the presence of imizadole ring in histidine. Saiga, Tanabe \& Nishimura 2003 discovered that acidic and/or basic amino acids played an important role in the chelation of metal ions by carboxyl and amino groups in their side chains.

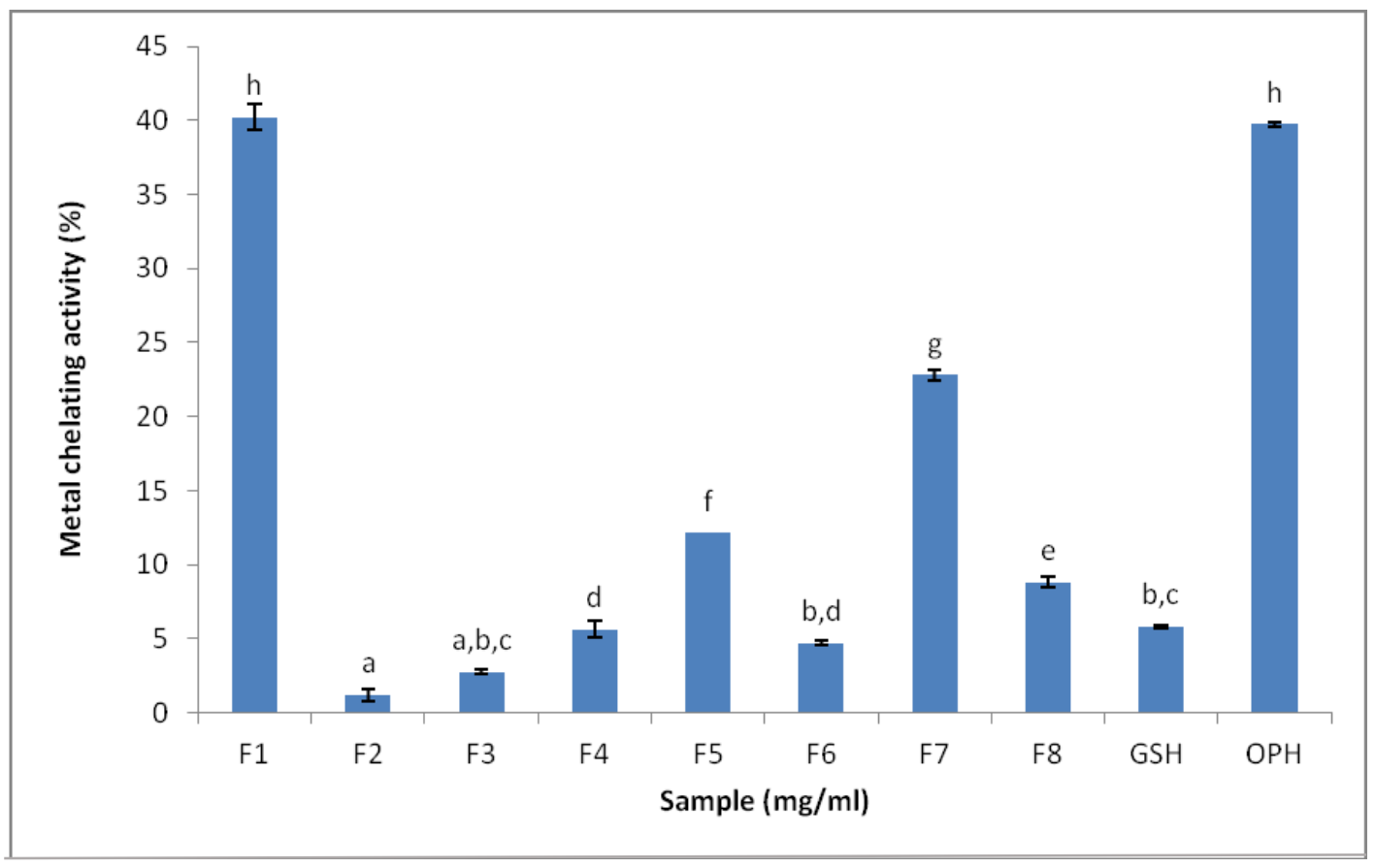

Fig. 3. Metal chelating of oat protein hydrolysate and peptide fractions. Values are means of triplicates \pm SD. Bars with same letters are not significantly different and bars with different letters are significantly different $(p<0.05)$. 


\subsection{Oxygen radical absorbance capacity assay (ORAC)}

This assay is often used to evaluate the ability of tissues, fluids and food products to scavenge peroxyl radicals (ROO`) (Prior, Wu \& Schaich 2005). In this research, the radical quenching ability of OPH and its RP-HPLC fractions were measured. AAPH was used as the peroxyl radical $\left(\mathrm{ROO}^{\circ}\right)$ generator. In the absence of antioxidant molecules, $\mathrm{ROO}^{\circ}$ react with the fluorescein probe (FL) causing damages and change in FL intensity. However in the presence of antioxidants, free radical damage of FL is inhibited. Data are based on the area under the curve (AUC) after the reaction is completed. The antioxidant capacity is calculated using net AUC obtained by subtraction of AUC blank from AUC of samples (Pinchuk et al. 2012). As shown in Figure 4, ORAC values were lowest for peptide fractions (F1-F7) ranged from 27.9 to $394.7 \mu \mathrm{M}$ $\mathrm{TE} / \mathrm{g}$. As retention time increased so does the content of organic solvent in eluent mixtures and the hydrophobic content of eluates. Based on this, it appeared that ORAC of F1-F7 is related to the hydrophobicity. Meanwhile, F1 contains salts and sugars that don't possess scavenging activities. Fraction 7 possessed the highest activity ( $844.8 \mu \mathrm{M} \mathrm{TE} / \mathrm{g})$. The fact that F8 had lower scavenging power than F7 was an indication that in addition to hydrophobicity, the sequence of peptides was important for peroxyl radical scavenging activity. None of the fractions have an ORAC value as high as that of the GSH (900.09 $\mu \mathrm{M}$ TE/g). ORAC values of OPH fractions are comparable to those of HPLC fractions of hemp seeds and salmon hydrolysates (Girgih, Udenigwe \& Aluko 2013), (Girgih et al. 2013). They are however greater than the maximum of $81 \mu \mathrm{M}$ TE/g that was reported for soybean protein hydrolysates (Darmawan, Bringe \& De Mejia 2010). 


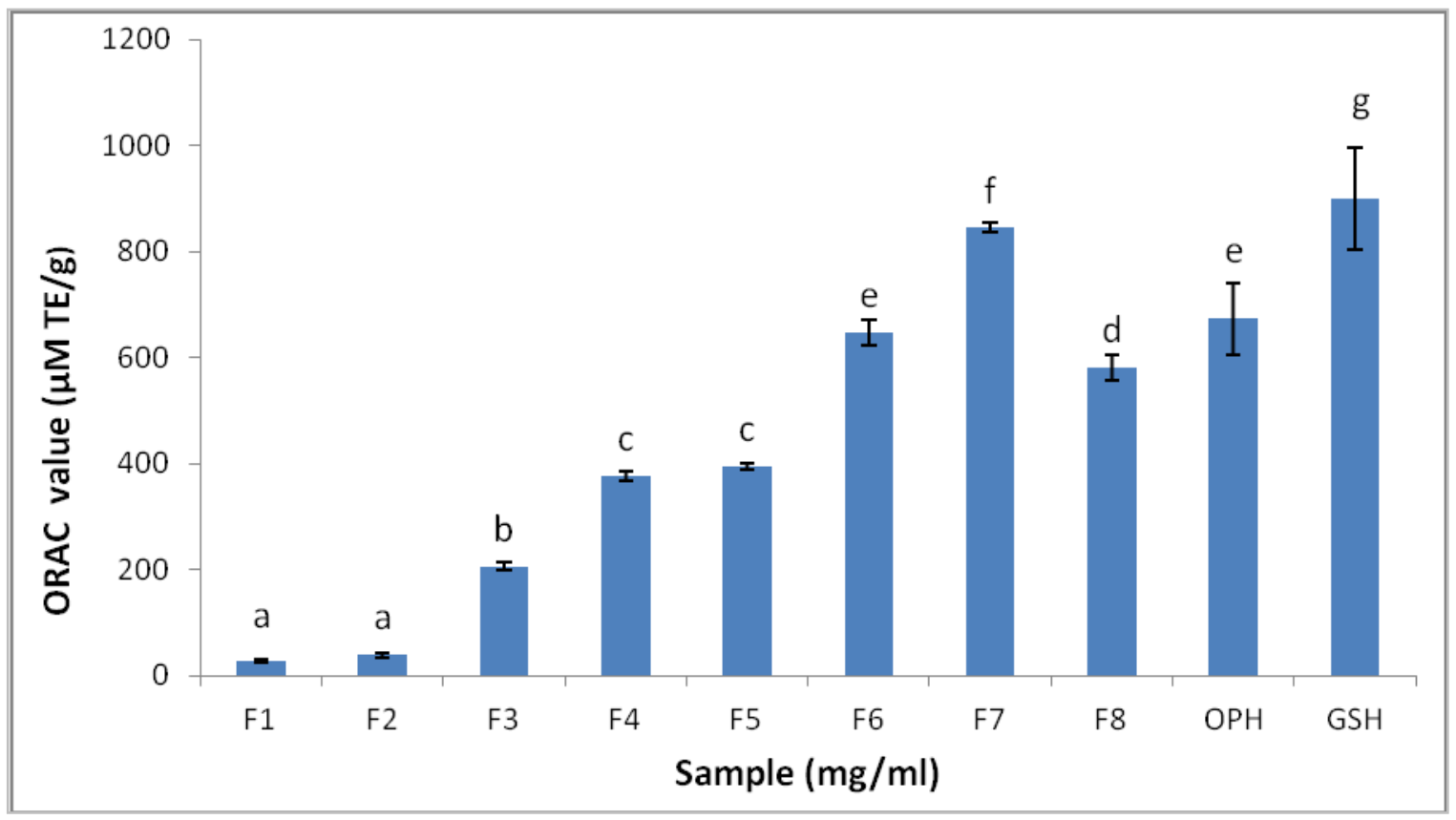

Fig. 4. Oxygen radical absorbance capacity of oat protein hydrolysate and peptide fractions. Values are means of triplicates \pm SD. Bars with same letters are not significantly different and bars with different letters are significantly different $(p<0.05)$.

\subsection{Superoxide radical scavenging assay}

Superoxide radicals were generated by the autoxidation of pyrogallol in alkaline solution (Li 2012). The reaction can be explained briefly; semiquinone 1 and 2 via quinone react to form purpurogallin Figure 5. Purpurogallin is a highly conjugated molecule formed from quinone that is easily detected by spectrophotometer. The generation of purpurogallin correlated with superoxide radical formation. Therefore in presence of molecules that scavenge superoxide radicals, the absorbance of purpurogallin is low and reflects the inhibition of $\mathrm{O}_{2}^{-\bullet}$, EDTA is added to chelate metal ions because they can accelerate the autoxidation of pyrogallol (Marklund, Marklund 1974), (Li 2012). 
<smiles>O=C1C=CC=C(O)C1=O</smiles>

quinone<smiles></smiles>

purpurpogallin

Fig. 5. Structure of quinone and purpurpogallin

As shown in Figure 6, the RP-HPLC peptide fractions at the concentrations tested possessed superoxide scavenging activities ranging from 34.9 to $51.2 \%$ compared to $22.09 \%$ for $\mathrm{OPH}$. These scavenging activities are similar to those reported for chickpea peptides (35-69\%) at 2 $\mathrm{mg} / \mathrm{mL}$ (Li et al. 2008) while the present results were obtained at $1 \mathrm{mg} / \mathrm{mL}$. These results show that RP-HPLC fractionation significantly increase the superoxide radical activity $(p<0.05)$ of most fractions compared to the $\mathrm{OPH}$. Protein hydrolysates and fractions of other food sources have been reported to possess varying scavenging abilities against superoxide radicals. For example, hemp seeds most hydrophilic peptide showed $41 \% \mathrm{O}_{2}^{-\bullet}$ scavenging activity which is similar to the value of F2 (43\%) but lower than F3 value (51.2\%) obtained in this work. Later eluting fractions of hemp seed hydrolyzed proteins had no noticeable activity at $1 \mathrm{mg} / \mathrm{ml}$ (Girgih, Udenigwe \& Aluko 2013). In contrast, F7 and F 8 of the protamex hydrolyzed oat proteins displayed $39.53 \%$ and $45.35 \% \mathrm{O}_{2}^{-\bullet}$ inhibition, respectively.

\subsection{Hydroxyl radical scavenging assay}

This assay method was performed to evaluate the samples ability to prevent the formation of $\mathrm{HO}^{\circ}$. In vitro, 1, 10-Phenanthroline is an iron chelator used for prevention of ironmediated $\mathrm{HO}^{\bullet}$ formation (de Avellar et al. 2004). 


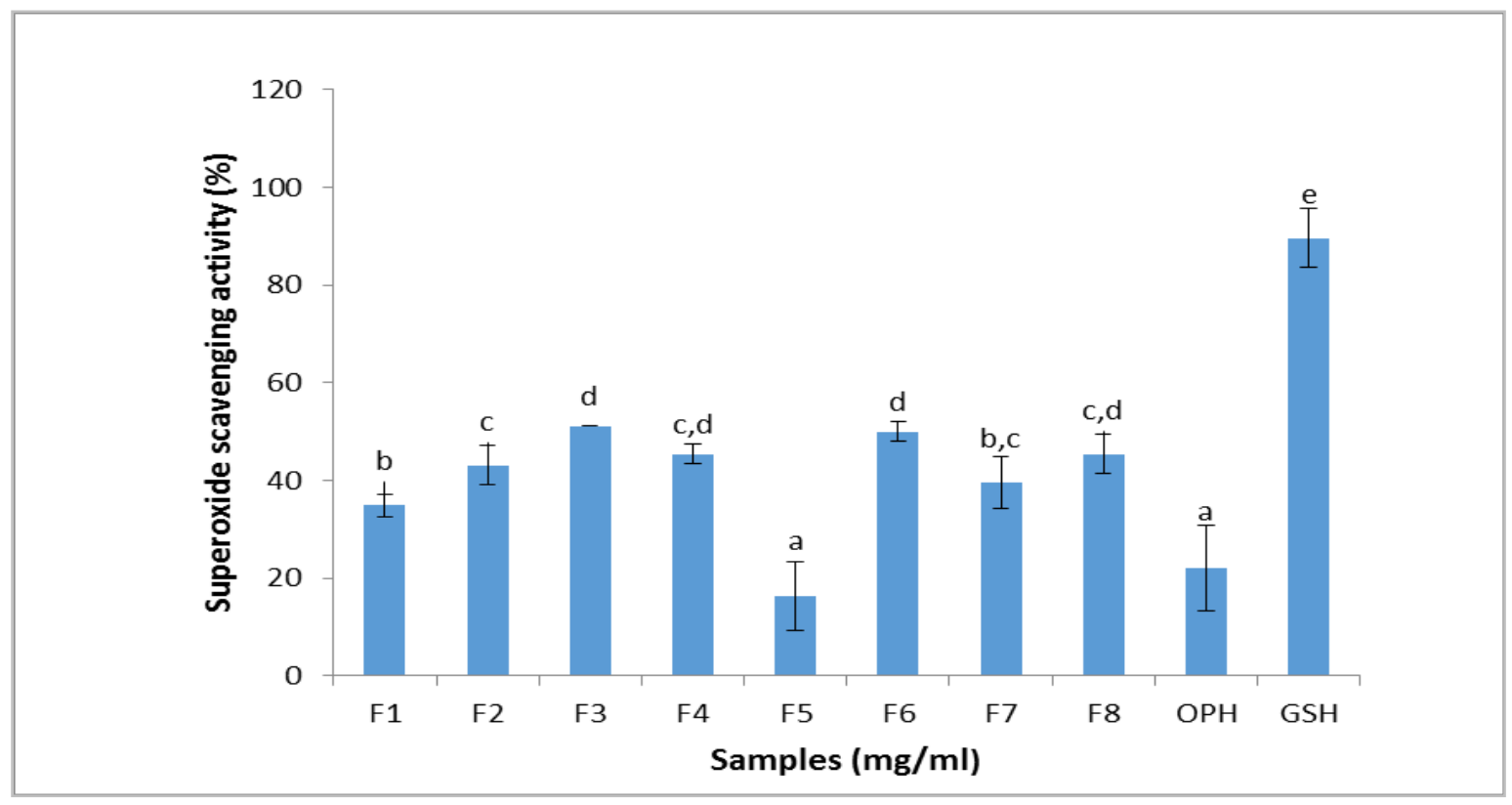

Fig. 6. Superoxide radical scavenging activity of oat protein hydrolysate and peptide fractions. Values are means of triplicates \pm SD. Bars with same letters are not significantly different and bars with different letters are significantly different $(p<0.05)$.

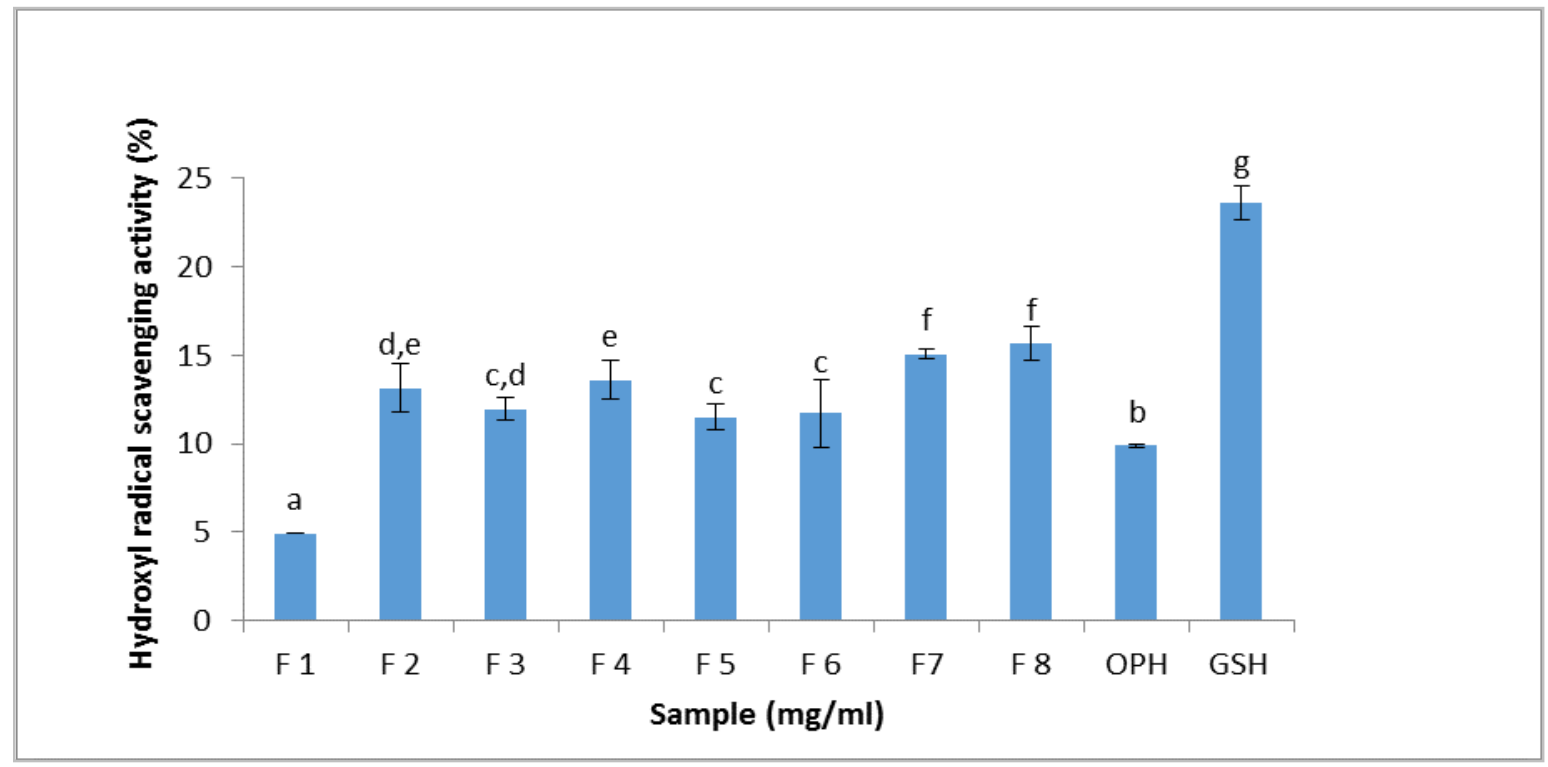

Fig. 7. Hydroxyl radical scavenging activity of oat protein hydrolysate and peptide fractions. Values are means of triplicates \pm SD. Bars with same letters are not significantly different and bars with different letters are significantly different $(p<0.05)$. 
As shown in Figure 7, results were expressed as percentage inhibition, the purified fractions F2, F4, F7 and F8 have significantly higher $(p<0.05)$ inhibition percentages (13.16, $13.61,15.05$ and $15.65 \%)$ at $2 \mathrm{mg} / \mathrm{ml}$ compared to the $\mathrm{OPH}(9.89 \%)$ but still lower than that of the GSH $(23.65 \%)(p<0.05)$. These results indicate that RP-HPLC fractionation can prevent ironmediated $\mathrm{HO}^{\bullet}$ formation by concentrating active peptides with a high degree of hydrophobicity in fractions F7 and F8. In fraction F2 and 4, the RP-HPLC may contain a high amount of histidine, which high activity could be attributed by its metal-chelating ability due to imidazole ring (Chan, Decker \& Feustman 1994). Girgih, Udenigwe \& Aluko 2013 performed the same assay on RPHPLC hemp seed peptide fractions but didn't obtain any activity for the 2 most hydrophobic fractions F7 and 8 were no activity was detected. The differences observed between RP-HPLC oat and hemp seed peptides could be explained by the different amino acid composition. Li et al. 2008 presented chickpea peptide fractions at $1.5 \mathrm{mg} / \mathrm{ml}$ showing hydroxyl radical scavenging activities between 38.42 and $81.39 \%$, which is much higher than in the present study. However, gel filtration was the separation technique performed, so the separation was based on the peptide size, not on the hydrophobicity degree.

\subsection{Inhibition of lipid peroxidation}

Fatty acids are the main building blocks of phospholipids and triacylglycerol. According to degree of fatty acid saturation, oxidation occurs (Shahidi, Zhong 2010). Unsaturated fatty acids undergo autoxidation. In lipids autoxidation, peroxyl radicals convert $\mathrm{Fe}^{+2}$ to $\mathrm{Fe}^{+3}$, ferric ion reacts with ammonium thiocyanate producing the colored complex ferric thiocyanate. Deep color of the complex is proportional to the presence of ROO ${ }^{\bullet}$ radical (Girgih T et al 2013). 
So in the presence of antioxidants the color intensity is lower. As shown in Figure 8 the control linoleic acid (LOA), an expected increase in peroxyl radical production was seen throughout the assay. Lower absorbance was seen in fractions 2, 3, 4 and $\mathrm{OPH}$, meaning that they inhibited lipid peroxidation. Peptides isolated from loach and walnuts contained hydrophobic amino acids in their sequence also showed inhibition of LOA oxidation (You et al. 2012), (Ning et al. 2012). So the high antioxidant activity of peptides leads to higher interaction of hydrophobic amino acid with $\mathrm{ROO}^{\circ}$ therefore inhibiting the propagation reaction of lipid peroxidation. Hydrophobic amino acids in the peptides neutralize peroxyl radical by donating hydrogen (Vijayakumar et al. 2013). On the other hand, peptide fractions 5-8 did not inhibit peroxyl radical formation.

\subsection{Mineral binding capacity}

This investigates the ability of $\mathrm{OPH}$ and peptide fractions to bind calcium thereby forming peptide-calcium complexes. The binding capacity was measured with a calcium ion selective electrode. As shown in Figure 9, increasing the concentration of peptide fractions did not increase the calcium binding capacity. Peptide fractions 5 and 7 were selected for this assay due to their noticeable antioxidant activity. The binding ranged from $0.6-1 \mathrm{mg} / \mathrm{L}$ (Figure 8) for peptide concentrations between 200 to $2000 \mathrm{mg}$ /L. Compared to the literature data, F5 and F7 had very weak calcium binding activity. The following peptides showed higher calcium binding capacity than oat bran F5 and F7. The calcium binding capacity of peptide from Alaska pollack pepsin hydrolysed $(250 \mathrm{mg} / \mathrm{L}$ ) binding capacity was found to be $32 \mathrm{mg} / \mathrm{L}$ and there was a correlation between binding capacity and peptide concentrations (Jung et al. 2006). 
In another study, oligophosphopeptide $(200 \mathrm{mg} / \mathrm{L})$ from hen egg yolk phosvitin, had a calcium binding capacity of $36.3 \mathrm{mg} / \mathrm{L}$. This activity was due to the presence of phosphoseryl group and to serine, threonine and aspartate in the egg yolk peptide (Jiang and Mine 2001). Pepsin hydrolysates of hoki frame ultra-filtered fraction exhibited higher calcium binding activity than to the hydrolysate. Further fractionation on hydroxyapatite affinity chromatography afforded a sub-fraction with similar calcium binding capacity of egg yolk phosvitin and Pollack hydrolysate. MS/MS was done on the Quadrupole-time-of-flight (QTOF) tandem mass spectrometer showed the peptide contained valine, leucine, serine, glycine and methionine amino acid that may have contributed to the activity (Jung, Kim 2007) (Jiang, Mine 2001) (Jung et al. 2006). Wheat germ proteins were hydrolyzed with several proteases and alcalase was the ideal protease to produce calcium binding peptides. Alcalase hydrolysates contained hydrophobic amino acids (valine, leucine, isoleucine and phenylalanine) and acidic amino acids (glutamate and aspartate) have protonation sites favoring deprotonation of peptides and calcium binding (Liu et al. 2013). These results indicate that the type of enzyme used for proteolysis, amino acids and peptide sequences have an influence on the calcium binding capacity. In this study oat bran proteins were hydrolyzed with protamex which does not seem to be a good protease for producing calcium binding peptides from this sample. 


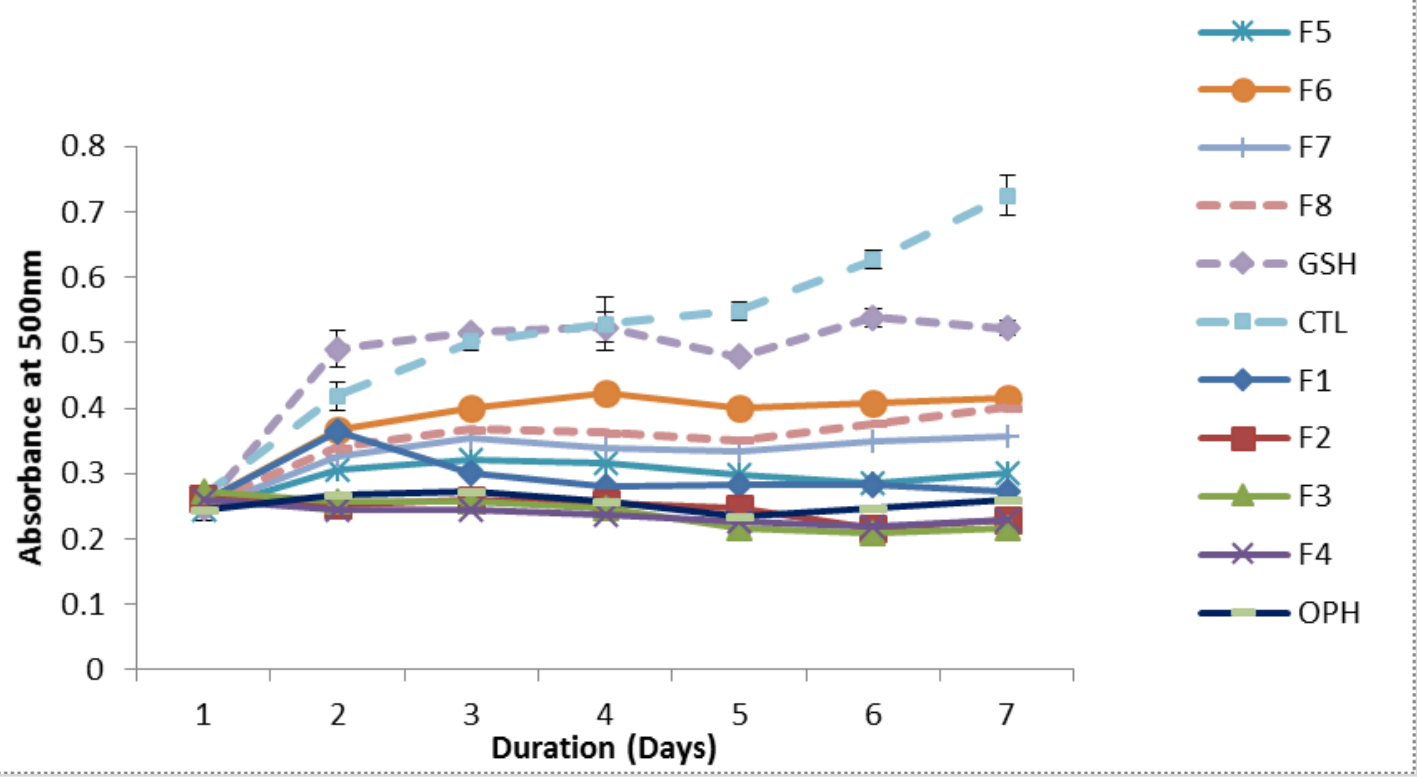

Fig.8. Inhibition of linoleic acid oxidation by oat protein hydrolysate and peptide fractions separated by RP-HPLC

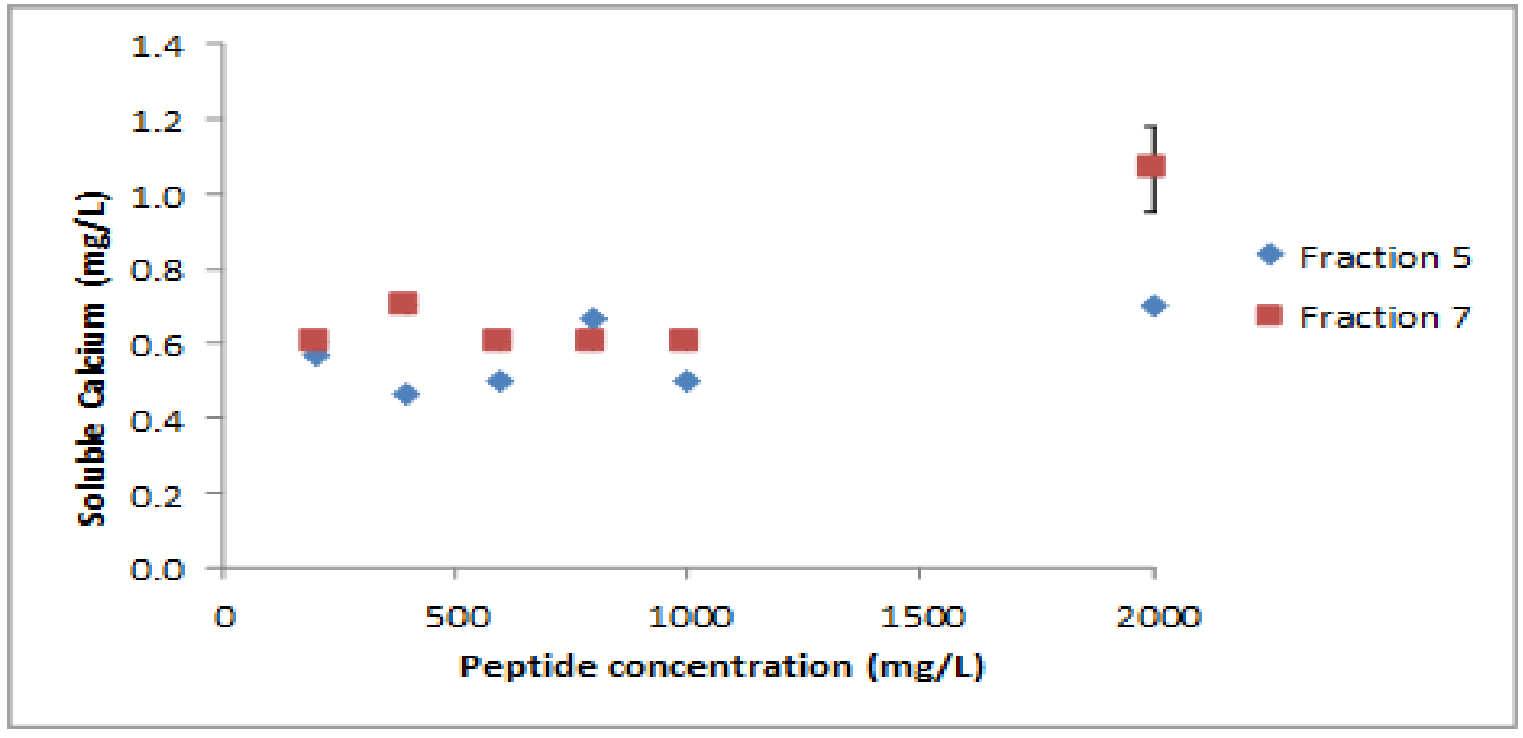

Fig. 9. In vitro calcium-binding capacity of peptide fractions 5 and 7 


\subsection{Mass spectrum analysis}

Tandem mass spectrometry was applied on multiple charged ions over 30 min on F5 and F7 Figure 10. and 12. F5 in the spectrum there are peaks at m/z 489.2774 and 489.7782 the mass difference between each peak is 0.5 $\mathrm{Da}$. So it is a double charged peptide shown in Figure 11. According to the Mascot search, the higher the score the more it is likely that the peptide sequence has a match in the database search. Fraction 5 peptides with score 14, 12, 12 their peptide sequence KMPNKINV, HCLMNTL and PESLTP respectively. On the other hand F7 peptides with score 20, 19, 17 had the following sequence MHLLLIKN, DEPSGLGSQ and DIVVT. The presence of leucine $(L)$, valine $(V)$, proline $(P)$ and methionine $(M)$ hydrophobic amino acids contribute to the antioxidant activity. Methionone donates hydrogen when it undergoes oxidation to methionine sulfoxide. In addition, acidic negatively charged amino acid glutamic acid (E) and aspartic acid (D) can contribute to the metal chelating activity (Ajibola et al. 2011).

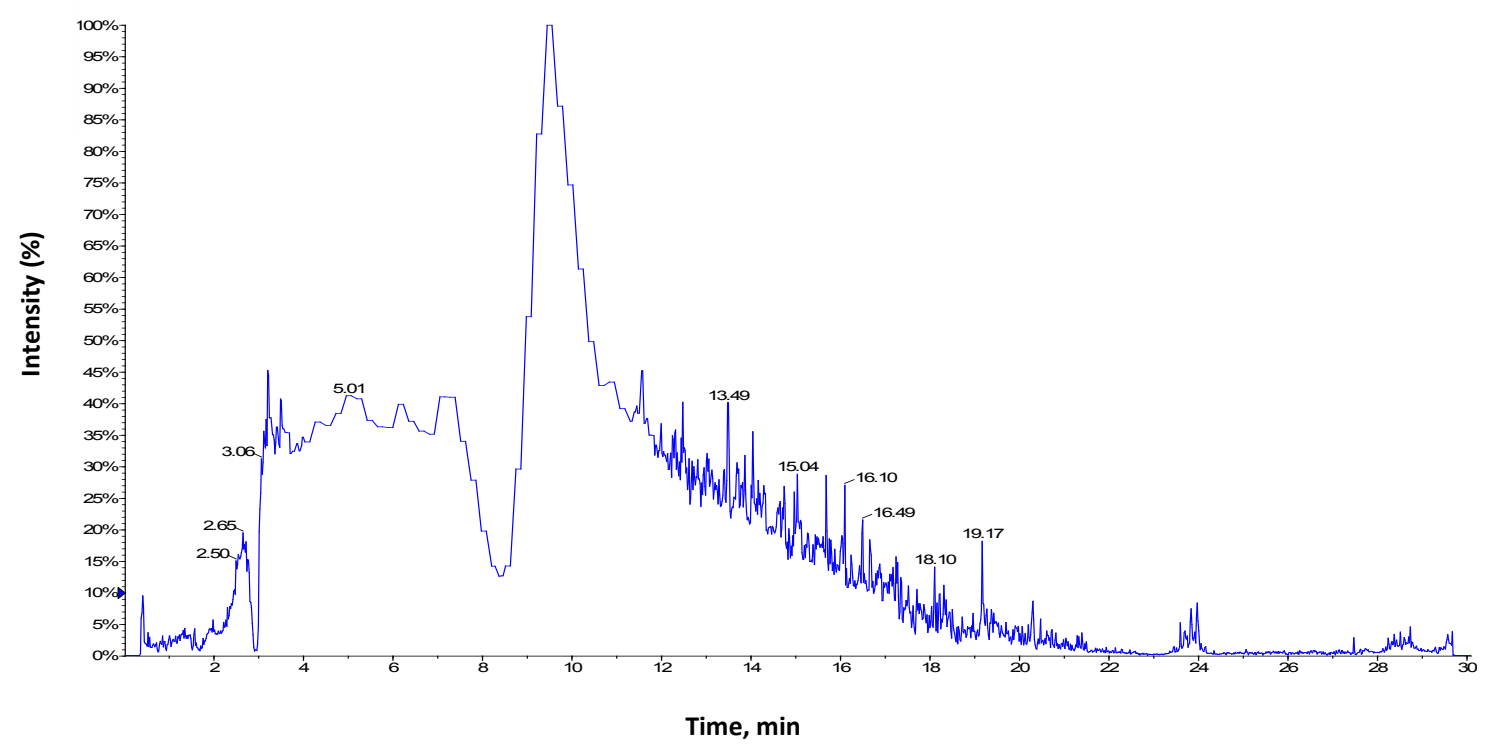

Fig. 10. Total ion count for F5 


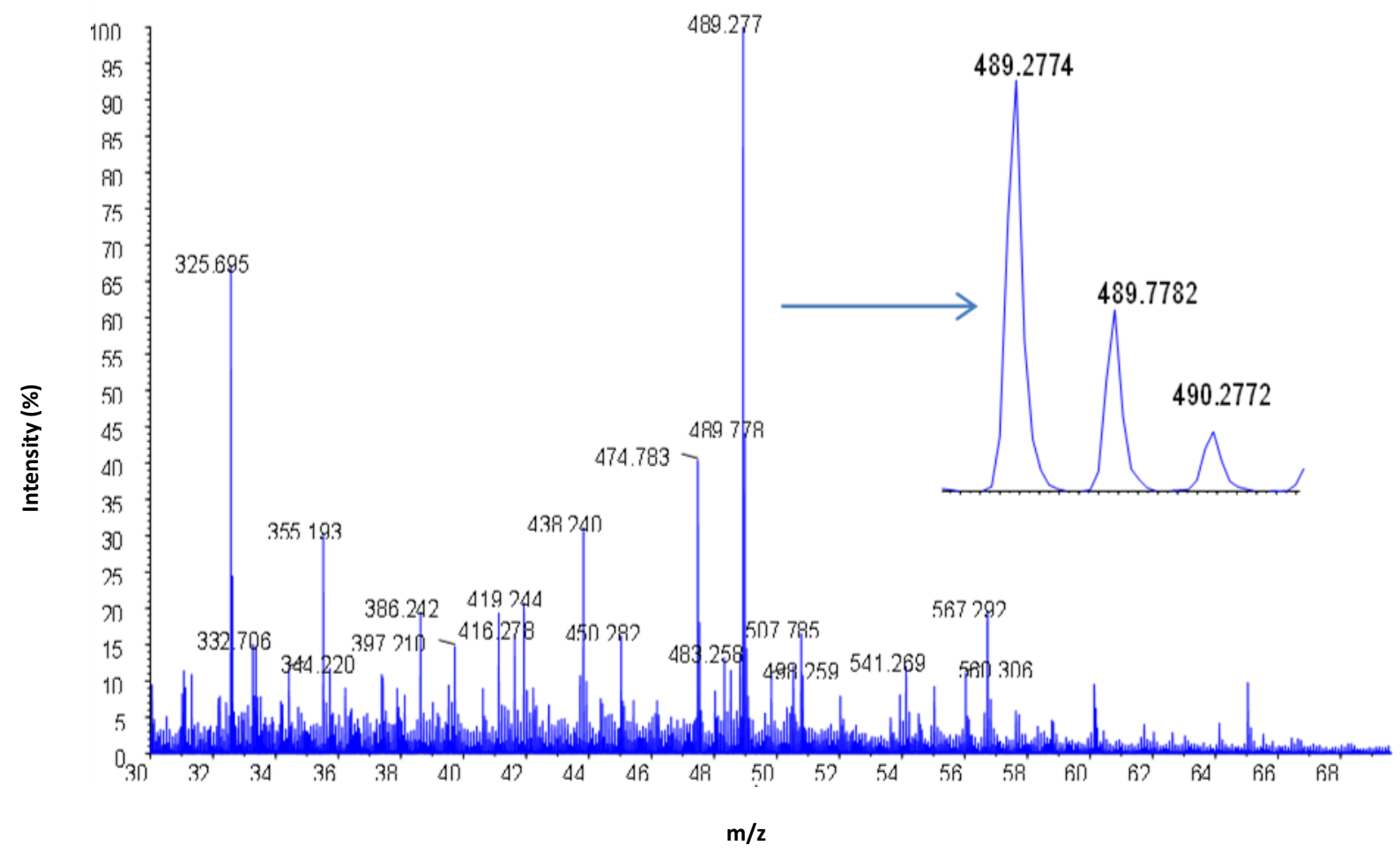

Fig. 11. MS/MS of Fig. 10 retention time 9-11 $\mathrm{min}$

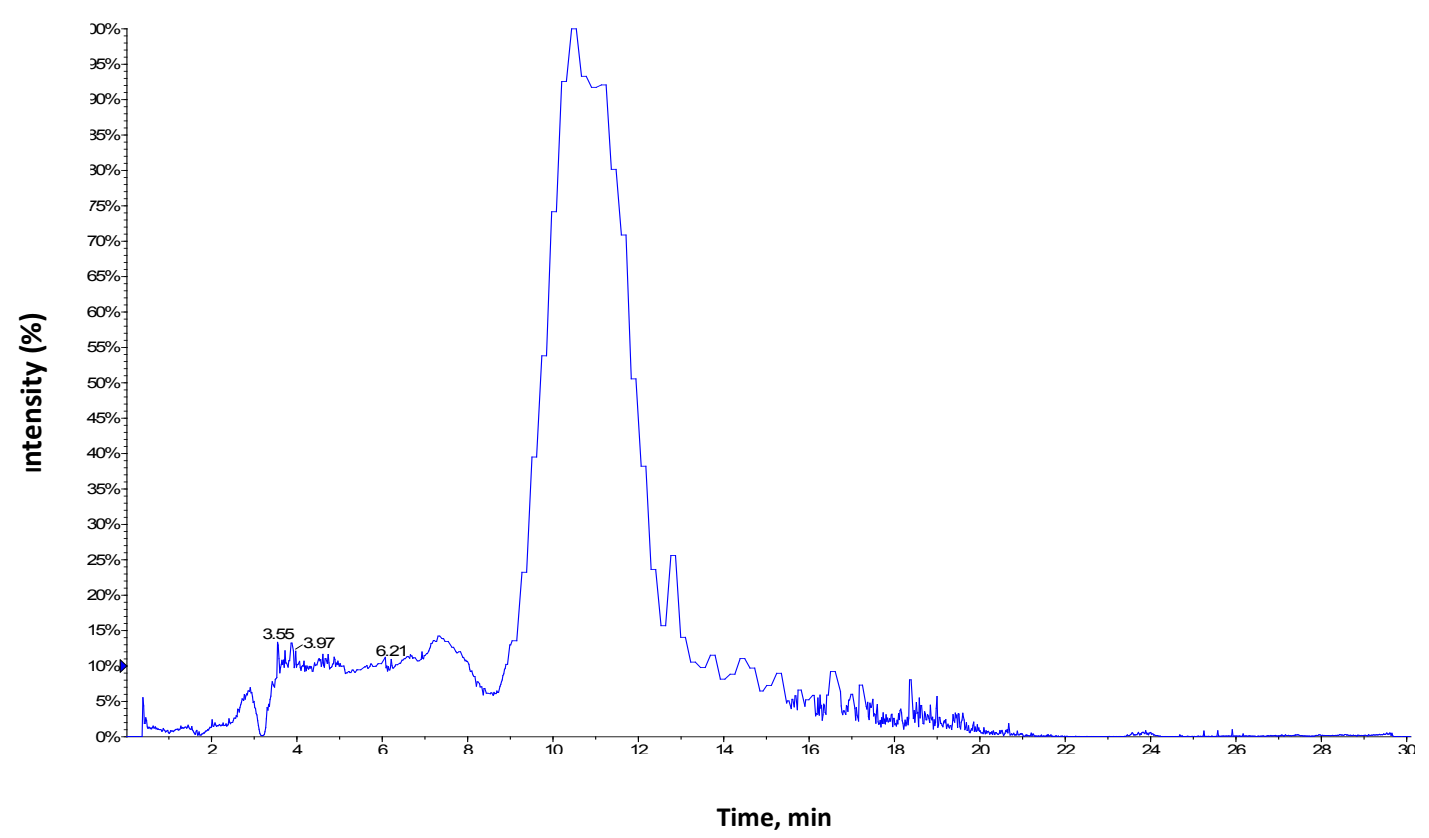

Fig. 12. Total ion count for F7 


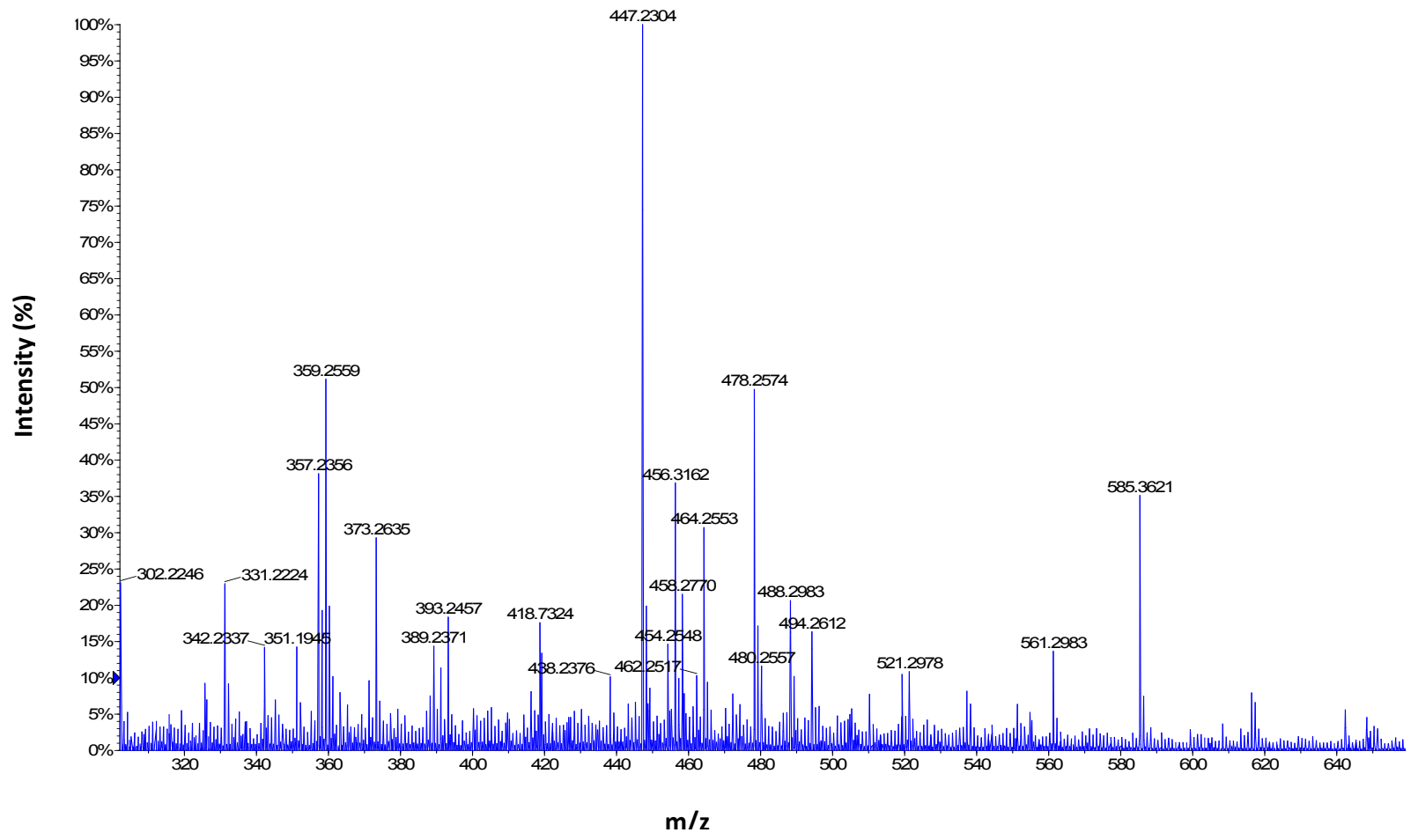

Fig. 13. MS/MS of Fig.12 retention time $9-13 \mathrm{~min}$ 


\section{Conclusion}

Many studies have been done to study the antioxidant activity of peptides from different plant sources using enzymatic digestion of proteins; however this is the first study to investigate the effect of using protamex protease enzyme on the antioxidant activity and mineral binding capacity of oat bran protein hydrolysates and RP-HPLC fractionated peptides. The results show that oat protein hydrolysates and peptide fractions possess antioxidant activity for various ROS. The small size of peptides had a great influence in increasing the radical quenching ability (ROO') in ORAC. The peptides and $\mathrm{OPH}$ had metal chelating activity better than GSH. So, in the presence of metal ions hydroxyl radical is formed through superoxide radical and hydrogen peroxide. So it is in favor to chelate metal ions to suppress the generation of hydroxyl radical in Fenton and Haber-weiss raction. As a result, decreasing the damage to biological molecules in the body as DNA and proteins and the related diseases to be developed. Moreover, oat protein hydrolysate and fractionated peptides exhibited higher linoleic acid oxidation in comparison to GSH. This can be a promising role for both the hydrolysate and peptide to be used in food industry in terms of protection against lipid peroxidation. Also their consumption depending on bioavailability in vivo can help maintain good blood circulation in blood vessels which decrease the incidence of blood clots and high blood pressure. Oat bran peptide protamex treated exhibited poor calcium binding capacity making it not likely to be good dietary source for patients with osteoporosis. 


\section{Future Work}

Oat bran protein hydrolysates and fractionated peptides can be of value in inhibiting lipid peroxidation and this can be tested in food and cell culture systems. The mass spectrometry was used to identify peptides in F5 and F7 but MS/MS was performed only on multiple charge ions. Peptides less than 1000 Da will have single charged. Future work can be done on both single and multiple charges ions in all fractions. The cytoprotective effect of fractions and potential peptides can be evaluated in cells like the intestinal cell Caco2 and the hepatic HepG2. Caco2 cells can also be used to determine the bioavailability of peptides. 


\section{References}

Ahmad, M., Zaffar, G., Dar, Z., A. \& Habib, M. 2014, "A review on oat (avena sativa L.) as a dual-purpose crop", Academic journals, vol. 9, no. 4, pp. 52-59.

Ajibola, C., F., Fashakin, J., B., Fagbemi, T., N. \& Aluko, R., E. 2011, "Effect of peptide size on antioxidant properties of African yam bean seed (Sphenostylis stenocarpa) protein hydrolysate fractions", International journal of molecular sciences, vol. 12, no. 10, pp. 6685-6702.

Arendt, E. \& Zannini, E. 2013, Cereal grains for the food and beverage industries, First edn, Woodhead.

Aristotelis, T., H., Anthony, K., T. \& Anne, J., M. 2011, "Enzymatic hydrolysis of fish frames using pilot Plant scale systems", Food and Nutrition Sciences, vol. 2, pp. 575-585.

Beermann, C., Euler, M., Herzberg, J. \& Stahl, B. 2009, "Anti-oxidative capacity of enzymatically released peptides from soybean protein isolate", European food research and technology, vol. 229, no. 4, pp. 637-644.

Bovell-Benjamin, A., C., Viteri, F., E., \& Allen, L., H. 2000, "Iron absorption from ferrous bisglycinate and ferric trisglycinate in whole maize is regulated by iron status", The American journal of clinical nutrition, vol.71, no.6, pp.1563-1569.

Braaten, J., T., Wood, P., J., Scott, F., W., Wolynetz, M.,S., Lowe, M.,K., Bradley, W., P. \& Collins, M.,W. 1994, "Oat beta-glucan reduces blood cholesterol concentration in hypercholesterolemic subjects", European journal of clinical nutrition, vol. 48, no. 7, pp. 465-474.

Briegera, K., Schiavonea, S., Miller Jr.b, F., J. \& Krausea, K. 2012, "Reactive oxygen species: from health to disease", Swiss Medical Weekly, vol. 142.

Butt, M., S., Tahir-Nadeem, M., Khan, M, K, I., Shabir, R. \& Butt, M., S. 2008, "Oat: unique among the cereals", European journal of nutrition, vol. 47, no. 2, pp. 68-79.

Cadenas, E. \& Sies, H. 1998, "The lag phase", Free Radical Research, vol. 28, pp. 601-609.

Chan, K.,M., Decker, E.,A. \& Feustman, C. 1994, "Endogenous skeletal muscle antioxidants", Critical Reviews in Food Science and Nutrition, vol. 34, no. 4, pp. 403-426.

Chen, D., Liu, Z., Huang, W., Zhao, Y., Dong, S., \& Zeng, M. 2013 "Purification and characterisation of a zinc-binding peptide from oyster protein hydrolysate" Journal of Functional Foods, vol.5, no.2, pp.689-697.

Clapham, D., E. 2007, "Calcium signaling", Cell, vol.131, no.6, pp. 1047-1058. 
Darmawan, R., Bringe, N.A. \& De Mejia, E.G. 2010, "Antioxidant capacity of alcalase hydrolysates and protein profiles of two conventional and seven low glycinin soybean cultivars", Plant Foods for Human Nutrition, vol. 65, pp. 233-240.

de Avellar, I.,G., Magalhães, M.,M., Silva, A.,B., Souza, L.,L., Leitão, A.,C. \& Hermes-Lima, M. 2004, "Reevaluating the role of 1,10-phenanthroline in oxidative reactions involving ferrous ions and DNA damage", Biochimica et Biophysica Acta, vol. 1675, pp. 44-53.

Decker, H. \& Van Holde, K., E. 2011, "Oxygen, Its Nature And Chemistry: What Is So Special About This Element?" in Oxygen and the evolution of life, Springer, Berlin; Heidelberg; New York, pp. 1-18.

FDA 1997, "Food labeling: Health claims; oats and coronary heart disease; final rule", Food and Drug Adminstration (FDA), vol. 62, pp. 3583-3601.

Ferraretto, A., Gravaghi, C., Fiorilli, A. \& Tettamanti, G. 2003 "Casein-derived bioactive phosphopeptides: role of phosphorylation and primary structure in promoting calcium uptake by HT-29 tumor cells" FEBS letters, vol.551, no.1, pp.92-98.

Foschia, M., Peressini, D., Sensidoni, A. \& Brennan, C., S. 2013, "The effects of dietary fibre addition on the quality of common cereal products", Journal of cereal science, vol. 58, no. 2, pp. 216-227.

García-Nebot, M., J., Barberá, R. \& Alegría, A. 2013 "Iron and zinc bioavailability in Caco-2 cells: Influence of caseinophosphopeptides" Food chemistry, vol.138, no.2, pp.1298-1303.

Gill, S., S. \& Tuteja, N. 2010," Reactive oxygen species and antioxidant machinery in abiotic stress tolerance in crop plants (Review)", Plant Physiology and Biochemistry, vol. 48, pp. 909-930.

Girgih, A., T., Udenigwe, C., C. \& Aluko, R., E. 2013, "Reverse-phase HPLC separation of hemp seed (Cannabis sativa L.) protein hydrolysate produced peptide fractions with enhanced antioxidant capacity", Plant foods for human nutrition, vol. 68, no. 1, pp. 39-46.

Girgih, A., T., Udenigwe, C., C., Hasan, F., M. \& Gill, T., A. 2013, "Antioxidant properties of Salmon (Salmo salar) protein hydrolysate and peptide fractions isolated by reverse-phase HPLC", Food Research International, vol. 52, pp. 315-322.

Guo, L., Hou, H., Li, B., Zhang, Z. \& Zhao, X. 2013 "Preparation, isolation and identification of ironchelating peptides derived from Alaska pollock skin" Process Biochemistry, vol.48, no.5-6, pp.988993.

Hansen, M., Sandström, B. \& Lönnerdal, B. 1996 " The effect of casein phosphopetides on zinc and calcium absorption from high phytate infant diets assessed in rat pups and caco-2 cells" Pediatric Research, vol.40, no.4, pp.547-552.

Hensley, K., Benaksas, E.,J., Bolli, R., Comp, P., Grammas, P., Hamdheydari, L., Mou, S., Pye, Q.,N., Stoddard, M.,F., Wallis, G., Williamson, K.,S., West, M., Wechter, W., J. \& Floyd, R.,A. 2004, "New 
perspectives on vitamin E: $\gamma$-tocopherol and carboxyethylhydroxychroman metabolites in biology and medicine (Review)", Free Radical Biology and Medicine, vol. 36, no. 1, pp. 1-15.

Huang, D., Ou, B., Hampsch-Woodill, M., Flanagan, J.,A. \& Prior, R.,L. 2002, " High throughput assay of oxygen absorbance capacity (ORAC) using a multichannel liquid handling system coupled with a microplate fluorescence reader in 96-well format", Journal of Agricultural and Food Chemistry, vol. 50, pp. 4437-4444.

Huang, W., H., Sun, J., He, H., Dong, H., W., \& Li, J., T. 2011, "Antihypertensive effect of corn peptides, produced by a continuous production in enzymatic membrane reactor, in spontaneously hypertensive rats", Food Chemistry, vol.128, no.4, 968-973.

Jiang, B. \& Mine, Y. 2001, " Phosphopeptides derived from hen egg yolk phosvitin: effect of molecular size on the calcium-binding properties", Bioscience, Biotechnology, and Biochemistry, vol. 65, pp. 1187-1190.

Jodayree, S., Smith, J., C. \& Tsopmo, A. 2012, "Use of carbohydrase to enhance protein extraction efficiency and antioxidative properties of oat bran protein hydrolysates", Food research international, vol. 46, no. 1, pp. 69-75.

Joshi, V., D., Mendhurwar, S., J. 2010, "Chapter 2: Blood" Physiology: Prep Manual for Undergraduates", eds. Mathur, B. pp. 72-75.

Jung, W., K., Karawita, R., Heo, S., J., Lee, B., J., Kim, S., K. \& Jeon, Y.J. 2006, "Recovery of a novel Cabinding peptide from Alaska Pollack (Theragra chalcogramma) backbone by pepsinolytic hydrolysis", Process Biochemistry, vol. 41, no. 9, pp. 2097-2100.

Jung, W., K., Kim, S, K. 2007, "Calcium-binding peptide derived from pepsinolytic hydrolysates of hoki (Johnius belengerii) frame" European Food Research and Technology, vol.224, no.6, pp. 763-767.

Kim, J.,R., Yoon, H.,W., Kwon, K.,S., Lee, S.,R. \& Rhee, S.,G. 2000, "Identification of proteins containing cysteine residues that are sensitive to oxidation by hydrogen peroxide at neutral $\mathrm{pH} . "$, The Annual Review of Biochemistry, vol. 283, pp. 214-221.

Kodama, T., Miyazaki, T., Kitamura, I., Suzuki, Y., Namba, Y., Sakurai, J. \& Inoue, S. 2004, " Effects of single and long-term administration of wheat albumin on blood glucose control: randomized controlled clinical trials", European journal of clinical nutrition, vol. 59, no. 3, pp. 384-392.

Korhonen, H. \& Pihlanto, A. 2003, "Food-derived bioactive peptides--opportunities for designing future foods", Current pharmaceutical design, vol. 9, no. 16, pp. 1297-1308.

Koyama, M., Naramoto, K., Nakajima, T., Aoyama, T., Watanabe, M. \& Nakamura, K. 2013, " Purification and identification of antihypertensive peptides from fermented buckwheat sprouts", Journal of Agricultural and Food Chemistry, vol. 61, no. 12, pp. 3013-3021. 
Kumar, S. 2011, "Free Radicals and antioxidants:Human and Food system", Advances in applied Science Research, vol. 2, no. 1, pp. 129-135.

Lásztity, R. 1998, "Oat grain-a wonderful reservoir of natural nutrients and biologically active substances", Food Reviews International, vol. 14, no. 1, pp. 99-119.

Li, X. 2012, " Improved pyrogallol autoxidation method: a reliable and cheap superoxide-scavenging assay suitable for all antioxidants" Journal of Agricultural and Food Chemistry, vol. 60, no. 25, pp. 6418-6424.

Li, Y., Jiang, B., Zhang, T., Mu, W. \& Liu, J. 2008, " Antioxidant and free radical-scavenging activities of chickpea protein hydrolysate (CPH)", Food Chemistry, vol. 106, no. 2, pp. 444-450.

Lia, A., Mekki, N., Juhel, C., Senft, M. \& Lairon, D. 1997, "Postprandial lipemia in relation to sterol and fat excretion in ileostomy subjects given oat-bran and wheat test meals" American Society for Clinical Nutrition, vol. 66, no. 2, pp. 357-365.

Liaset, B., Nortvedt, R., Lied, E. \& Espe, M. 2002, "Studies on the nitrogen recovery in enzymic hydrolysis of Atlantic salmon (Salmo salar, L.) frames by Protamex ${ }^{\mathrm{TM}}$ protease"Process Biochemistry, vol. 37, no. 11 , pp. 1263-1269.

Lijuan, Z., Chen, J., Xueyan, T. \& Youling, X. 2008, "Reducing, radical scavenging, and chelation properties of in vitro digests of alcalase-treated zein hydrolysate", Journal of Agricultural and Food Chemistry, vol. 56, pp. 2714-2721.

Liu, F., R., Wang, L., Wang, R. \& Chen, Z., X. 2013, " Calcium-Binding Capacity of Wheat Germ Protein Hydrolysate and Characterization of Peptide-Calcium Complex", Journal of agricultural and food chemistry, vol. 6, no. 31, pp. 7537-7544.

Lönnerdal, B., O. 2000, "Dietary factors influencing zinc absorption", The Journal of nutrition, vol.130, no.5, pp.1378S-1383S.

Lv, Y., Bao, X., L., Yang, B., C., Ren, C., G., \& Guo, S., T. 2008 "Effect of Soluble Soybean Protein Hydrolysate-Calcium Complexes on Calcium Uptake by Caco-2 Cells" Journal of food science, vol.73, no.7 pp.H168-H173.

Madhujith, T. \& Shahidi, F. 2007, "Antioxidative and antiproliferative properties of selected barley (Hordeum vulgarae L.) cultivars and their potential for inhibition of low-density lipoprotein (LDL) cholesterol oxidation", Journal of Agricultural and Food Chemistry, vol. 55, pp. 5018-5024.

Mandal, S., Yadav, S., Yadav, S. \& Nema, R., K. 2009, "Antioxidants: A Review", Journal of Chemical and Pharmaceutical Research, vol. 1, no. 1, pp. 102-104.

Margis, R., Dunan, C., Teixeira, F., K. \& Pinheiro, M., M. 2008, "Glutathione peroxidase family - an evolutionary overview", Federation of European Biochemical Societies, vol. 275, pp. 3959-3970. 
Marklund, S. \& Marklund, G. 1974, "Involvement of the superoxide anion radical in the autoxidation of pyrogallol and a convenient assay for superoxide dismutase", European Journal of Biochemistry, vol. 47, no. 3, pp. 469-474.

Markwell, M., A., K, Haas S., M., Bieber L., L. \& Tolbert N.,E. 1978, "A modification of the Lowry procedure to simplify protein determination in membrane and lipoprotein samples", Analytical Biochemistry, vol. 87, pp.206-210.

Mate's, J., M., Pe'rez-go'mez, C. \& De Castro, I., N. 1999, "Antioxidant Enzymes and Human Diseases", Clinical Biochemistry, vol. 32, no. 8, pp. 595-603.

Matz, S., A. 1991, Chemistry and Technology of Cereals as Food and Feed, Second edn , USA.

Megías, C., Pedroche, J., Yust, M., M., Girón-Calle, J., Alaiz, M., Millán, F. \& Vioque, J. 2008, "Production of copper-chelating peptides after hydrolysis of sunflower proteins with pepsin and pancreatin" LWT-Food Science and Technology, vol. 41, no.10, pp.1973-1977.

Meisel, H. 2004, "Multifunctional peptides encrypted in milk proteins", Biofactors, vol. 21, no. 1, pp. 5561.

Meisel, H., Bernard, H., Fairweather-Tait, S., Fitz Gerald, R., J., Hartmann, R., Lane, C., N., McDonagh, D., Teucher, B. \& Wal, J., M. 2003 "Detection of caseinophosphopeptides in the distal ileostomy fluid of human subjects" British Journal of Nutrition, vol.89, no.3, pp.351-359.

Ning, C., Hongmei, Y., Yi, S., Jun, N. \& Shuying, L. 2012, "Purification and identification of antioxidant peptides from walnut (Juglans regia L.) protein hydrolysates", Peptides, vol. 38, pp. 344-349.

Nollet, L., Van der Klis, J., D., Lensing, M. \& Spring, P. 2007, "The effect of replacing inorganic with organic trace minerals in broiler diets on productive performance and mineral excretion", The Journal of Applied Poultry Research, vol.16, no.4, pp. 592-597.

Nordberg, j. \& Arner, E., S., J. 2001, "Reactive Oxygen Species, Antioxidants, and the mammalian thioredoxin system", Free Radical Biology and Medicine, vol. 31, no. 11, pp. 1287-1312.

Pandey, K., B. \& Rizvi, S., I. 2009, "Plant polyphenols as dietary antioxidants in human health and disease", Oxidative Medicine and Cellular Longevity, vol. 2, no. 5, pp. 270-278.

Peterson, D., M. 2004, Oat - a multifunctional grain. " $7^{\text {th }}$ International Oat Conference" Report 15.

Pinchuk, I., Shoval, H., Dotan, Y. \& Lichtenberg, D. 2012, "Evaluation of antioxidants: Scope, limitations and relevance of assays ", Chemistry and Physics of Lipid, vol. 165, pp. 638-647.

Pownall, T., L., Udenigwe, C., C. \& Aluko, R., E. 2010, "Amino acid composition and antioxidant properties of pea seed (Pisum sativum L.) enzymatic protein hydrolysate fractions", Journal of Agricultural and Food Chemistry, vol. 58, pp. 4712-4718. 
Prakash, S., Sunitha, J. \& Hans, M. 2010, "Role of coenzyme Q10 as an antioxidant and bioenergizer in periodontal diseases", Indian journal of pharmacology, vol. 42, no. 6, pp. 334-337.

Preiser, J., C. 2012, "Oxidative Stress ", Journal of Parenteral and Enteral Nutrition, vol. 36, pp. 147-154.

Prior, L., R., Wu, X. \& Schaich, K. 2005, "Standardized methods for the determination of antioxidant capacity and phenolics in foods and dietary supplements", Journal of Agricultural and Food Chemistry, vol. 53, pp. 4290-4302.

Pryor, W. 2000, "Vitamin E and heart disease: basic science to clinical intervention trials (Review)", Free Radical Biology and Medicine, vol. 28, no. 1, pp. 141-164.

Rahman, K. 2007, "Studies on free radicals, antioxidants, and co-factors.", Clinical Interventions in Aging, vol. 2, no. 2, pp. 219-236.

Rajapakse, N., Mendis, E., Jung, W., Je, J. \& Kim, S. 2005, "Purification of a radical scavenging peptide from fermented mussel sauce and its antioxidant properties", Food Research International, vol. 38, no. 2 , pp. 175-182.

Reuter, S., Gupta S, C., Chaturvedi, M., M. \& Aggarwal, B., B. 2010, "Oxidative stress, inflammation, and cancer: How are they linked? ", Free Radical Biology and Medicine, vol. 49, no. 11, pp. 16031616.

Rho, S., J., Park, S., Ahn, C., W., Shin, J., K. \& Lee, H., G. 2007, "Dietetic and hypocholesterolaemic action of black soy peptide in dietary obese rats", Journal of the Science of Food and Agriculture, vol. 87, pp. 908-913.

Saiga, A., Tanabe, S. \& Nishimura, T. 2003, "Antioxidant activity of peptides obtained from porcine myofibrillar proteins by protease treatment ", Journal of Agricultural and Food Chemistry, vol. 51, pp. 3661-3667.

Sarmadi, B., H. \& Ismail, A. 2010, "Antioxidative peptides from food proteins: A review", Peptides, vol. 31, no. 10, pp. 1949-1956.

Saskatchewan ministry of agriculture. September 2011, Factsheet oat production markets. Available: http://www.agriculture.gov.sk.ca/Default.aspx?DN=68b33116-9944-4df6-8575-5fc379b84d3b (0111-2014, 10:08 PM)

Sayar, S. \& White, P., J. 2011, "Chapter 7: Oat Starch: Physicochemical Properties and Function " in OATS: Chemistry and Technology, eds. F. Webster H. \& P. Wood J., Second edn, pp. 109-122.

Schneider, C. D. \& Oliveira, A. R. D. 2004, "Oxygen free radicals and exercise: mechanisms of synthesis and adaptation to the physical training", Revista Brasileira de Medicina do Esporte, vol. 10, no.4, pp. 308-313. 
Scholz-Ahrens, K., E. \& Schrezenmeir, J. 2000, "Effects of bioactive substances in milk on mineral and trace element metabolism with special reference to casein phosphopeptides", British Journal of Nutrition, vol. 84, pp. 147-153.

Shahidi, F. \& Zhong, Y. 2010, "Lipid oxidation and improving the oxidative stability ", Chemical Society Reviews, vol. 39, no. 11, pp. 4067-4079.

Sies, H. \& Stahl, W. 1995," Vitamins E and C, 6-carotene, and other carotenoids as antioxidants ", The American Journal of Clinical Nutrition, vol. 62, pp. 1315-1321.

Stańczyk, M., Gromadzińska, J. \& Wasowicz, W. 2005, "Roles of reactive oxygen species and selected antioxidants in regulation of cellular metabolism", International Journal of Occupational Medicine and Environmental Health, vol. 18, no. 1, pp. 15-26.

Stevens, E., J., Armstrong, K., W., Bezar, H.J. \& Griffin, W.B. 2004, Fodder Oats: An Overview Agriculture and Consumer Protection., Rome.

Strychar, R. 2011, "Chapter 1: World Oat Production, Trade, and Usage" in OATS: Chemistry and Technology, F. Webster H. \& P. Wood J., Second edn, pp. 1-10.

Surek, H., Hayward, J, V, M., Dyfed, S., Y. \& EB, U. 1997, " Isozyme variation among some European and American oat cultivars", journal of the Aegean Agricultural Research Institute, vol. 7, no. 1, pp. 9-20.

Tester, R., F., Karkalas, J. \& Qi, X. 2004, "Starch-composition, fine structure and architecture ", Journal of cereal science, vol. 39, pp. 151-165.

Theobald, H., E. 2005, "Dietary calcium and health", Nutrition Bulletin, vol.30, no.3, pp.237-277.

Truswell, A., S. 2002, "Cereal grains and coronary heart disease Review", European journal of clinical nutrition, vol. 56, pp. 1-14.

Vijayakumar, M., Noorlidah, A., Bakrudeen, A., Ahmed, A., Priya, K. \& Rosna, M.,T. 2013, " Marine derived bioactive peptides: Their cardioprotective activities and potential applications" in Marine Proteins and Peptides: Biological Activities and Application, ed. S. Kim K., First edn, Wiley and Sons, , pp. 499-508.

Walther, B. \& Sieber, R. 2011, "Bioactive proteins and peptides in foods", International Journal for Vitamin and Nutrition Research, vol. 81, no. 23, pp. 181-191.

Wang, C., Li., B., \& Ao, J. 2012, "Separation and identification of zinc-chelating peptides from sesame protein hydrolysate using IMAC-Zn ${ }^{2+}$ and LC-MS/MS", Food Chemistry, vol.134, no.2, pp.1231-1238.

Welch, R., W. 2011, "Chapter 6: Nutrient Composition and Nutritional Quality of Oats and Comparisons with Other Cereals" in OATS: Chemistry and Technology, ed. Francis H. Webster, Francis Webster \& Associates, Branson, Missouri, U.S.A. and Peter J. Wood, Guelph Food Research Centre, Guelph, Ontario, Canada, Second edn, pp. 95-107. 
Welch, R., W., Hayward, M., V. \& Jones, D, I, H. 1983, "The composition of oat husk and its variation due to genetic and other factors", Journal of the Science of Food and Agriculture, vol. 34, pp. 417-426.

Whole grains council 2013, Whole grains council. Available: http://wholegrainscouncil.org/whole-grains101/types-of-oats (12-11-2014, 2:00 PM)

Willcox, J., K., Ash, S., L. \& Catignani, G.,L. 2004, "Antioxidants and prevention of chronic disease", Critical Reviews in Food Science and Nutrition, vol. 44, pp. 275-295.

Wood, P.,J., Braaten, J.,T., Scott, F.,W., Riedel, K.,D., Wolynetz, M.,S. \& Collins, M.,W. 1994, "Effect of dose and modification of viscous properties of oat gum on plasma glucose and insulin following an oral glucose load", The british journal of nutrition, vol. 72, no. 5, pp. 731-743.

Wu, H., Liu., Z., Zhao, Y. \& Zeng, M. 2012 "Enzymatic preparation and characterization of iron-chelating peptides from anchovy (Engraulis japonicus) muscle protein" Food Research International, vol. 48, no.2, pp.435-441.

You, L., Ren, J., Yang, B., Regenstein, J. \& Zhao, M. 2012," Antifatigue activities of loach protein hydrolysates with different antioxidant activities", Journal of Agricultural and Food Chemistry, vol. 60 , no. 50, pp. 12324-12331.

Zhang, J., Zhang, H., Wang, L., Guo, X., Wang, X. \& Yao, H. 2010, "Isolation and identification of antioxidative peptides from rice endosperm protein enzymatic hydrolysate by consecutive chromatography and MALDI-TOF/TOF MS/MS ", Food Chemistry, vol. 119, no. 1, pp. 226-234.

Zhang, T., Li,Y., Miao, M. \& Jiang, B. 2011, "Purification and characterisation of a new antioxidant peptide from chickpea (Cicer arietium L.) protein hydrolysates", Food Chemistry, vol.128, no.1, pp.28-33.

Zhengjun, X., Junrong, H., Xueming, X. \& Jin, Z. 2008, "Antioxidant activity of peptides isolated from alfalfa leaf protein hydrolysate", Food Chemistry, vol. 111, pp. 370-376.

Zhu, K., Zhou, H. \& Qian, H. 2006, "Antioxidant and free radical-scavenging activities of wheat germ protein hydrolysates (WGPH) prepared with alcalase", Process Biochemistry, vol. 41, no. 6, pp. 1296-1302. 